\title{
Ground/satellite observations and atmospheric modeling of dust storms originating in the high Puna-Altiplano deserts (South America): Implications for the interpretation of paleo-climatic archives
}

\author{
D.M. Gaiero, ${ }^{1}$ L. Simonella, ${ }^{1}$ S. Gassó, ${ }^{2}$ S. Gili, ${ }^{1}$ A.F. Stein, ${ }^{3}$ P. Sosa,${ }^{4}$ R. Becchio, ${ }^{4}$ \\ J. Arce, ${ }^{5}$ and H. Marelli ${ }^{5}$ \\ Received 11 September 2012; revised 6 November 2012; accepted 7 November 2012; published 13 May 2013.
}

[1] This study provides a detailed description of the sources, transport, dispersion, and deposition of two major dust events originating from the high-altitude subtropical PunaAltiplano Plateau $\left(15-26^{\circ} \mathrm{S} ; 65-69^{\circ} \mathrm{W}\right)$ in South America. A long and severe drought provided the right conditions for the onset of both events in July 2009 and 2010. Dust was transported SE and deposited over the Pampas region and was observed to continue to the Atlantic Ocean. Dust monitoring stations located downwind recorded both events, and samples were characterized through chemical and textural analysis. Through a combination of meteorological data and satellite observations (CALIPSO and MODIS detectors), we estimate the emission flux for the 2010 event. This estimate was used to constrain the Hybrid Single Particle Lagrangian Integrated Trajectory (HYSPLIT) transport model and simulate the dust event. Both satellite imagery and model results agree in the location and extension of the dust cloud. CALIPSO detected dust between $\sim 6000$ and $\sim 8500 \mathrm{~m}$ a.s.1., which remained at this height during most of its trajectory. The dust cloud mixed with a strong convective system in the region, and the associated precipitation brought down significant amounts of dust to the ground. Dust particle size analysis for both events indicates that near the sources dust samples show median modes of 12.4-14.1 $\mu \mathrm{m}$, similar to modes observed $1300 \mathrm{~km}$ away. Chemical composition of sediments from potential dust sources shows distinct signatures within the Puna-Altiplano Plateau, the Puna sector being clearly different from the Altiplano area. In addition, both sources are markedly different from the Patagonian chemical fingerprint.

These results have important implications to improve the interpretation of paleo-

environmental archives preserved on the Argentine loess, Antarctic ice cores, and Southern Ocean marine sediments.

Citation: Gaiero, D. M., L. Simonella, S. Gassó, S. Gili, A. F. Stein, P. Sosa, R. Becchio, J. Arce, and H. Marelli, (2013), Ground/ satellite observations and atmospheric modeling of dust storms originating in the high Puna-Altiplano deserts (South America): Implications for the interpretation of paleo-climatic archives, J. Geophys. Res. Atmos., 118, 3817-3831, doi:10.1002/jgrd.50036.

\section{Introduction}

[2] During the last few decades, the scientific community has become aware of dust as an important component of the Earth system and also of its great source of uncertainty in climate modeling [Maher et al., 2010]. Dust is strongly linked to the climate system in several ways: (1) it plays an important role in biogeochemical processes because when deposited on

${ }^{1}$ CICTERRA/FCEFyN, Universidad Nacional de Córdoba, Córdoba, Argentina.

${ }^{2}$ GESTAR, Morgan State University, Baltimore, MD, USA.

${ }^{3}$ ERT, Inc., on assignment to Air Resources Laboratory, National Oceanic and Atmospheric Administration, College Park, MD, USA.

${ }^{4}$ Universidad Nacional de Salta, Salta, Argentina.

${ }^{5}$ INTA, Marcos Juárez, Provincia de Córdoba, Argentina.

Corresponding author: D.M. Gaiero, CICTERRA/FCEFyN, Universidad Nacional de Córdoba, Córdoba, Argentina. (dgaiero@efn.uncor.edu)

(C)2013. American Geophysical Union. All Rights Reserved. 2169-897X/13/10.1002/jgrd.50036 land surfaces it can contribute to soil development and nutrient increase in terrestrial ecosystems [Ravi et al., 2011], (2) dust travels long distances and can supply key elements to the surface ocean (e.g., Fe) that are essential to phytoplankton growth and therefore to the global carbon cycle [Martin et al., 1990; Jickells et al., 2005], and (3) it can significantly impact the radiative balance of the atmosphere by cooling (via scattering) or heating (via absorption) and then disrupt the cloud formation and precipitation processes [Tegen et al., 1996; Sokolik et al., 2001; Miller et al., 2004].

[3] Important knowledge gaps exist in our understanding of the location of the dust source areas, emission rates, transport and deposition mechanisms, and the properties of dust in terms of its textural, mineralogical, and chemical composition. Most of the information on these aspects is contained in studies of Saharan and Asian dust. There is, therefore, a dearth of studies on dust sources located in the Southern Hemisphere, particularly in South American deserts. In this region, the estimates for the magnitude of the dust fluxes and properties are largely 
based on model results [Ginoux et al., 2001; Zender et al., 2003; Liu et al., 2003, 2008; Albani et al., 2011]. There is a notable lack of observations that can corroborate these model estimates.

[4] In South America, potential dust source areas are mainly located in a continuous N-S band of arid and semi-arid terrains extending from the coast of Peru to the coast of Patagonia ("arid diagonal"). Based on an aerosol absorption index derived from the Total Ozone Mapping Spectrometer (TOMS), Prospero et al. [2002] identified, apart from Patagonia, the Puna $\left(22-26^{\circ} \mathrm{S}, 65-69^{\circ} \mathrm{W}\right)$ and the Altiplano $\left(15-22^{\circ} \mathrm{S}\right.$, $\left.65-69^{\circ} \mathrm{W}\right)(\mathrm{PAP})$ as areas with important dust activity year round. The PAP area is influenced by the subtropical jet stream [Koch et al., 2006], which intensifies during the austral winter and can have very strong associated winds (gusts over $100 \mathrm{~m} \mathrm{~s}^{-1}$ have been recorded [Milana, 2009]) that lead to the development of sizable dust storms. The region consists mostly of dried-out playas and alluvial fans, containing large quantities of silt eroded from neighboring mountains. The patterns and mechanisms of dust entrainment, transport, and deposition, as well as the chemical properties, remain unexplored subjects for this region.

[5] On the basis of indirect evidence, it was suggested that dust emitted from the Puna-Altiplano plateau could represent an important present and past dust supply for the Southern Hemisphere, thus explaining the loess accumulation in the Pampean region and the isotopic composition of sediment cores from the Southern Ocean and dust trapped in the Antarctic ice sheet (Gaiero, 2007). Moreover, dust exported from this region could have implications for the biogeochemistry of the Atlantic and the Southern Ocean. A better idea of how dust could be deflated and transported from the PAP was recently made possible through satellite observations of two dust storms that occurred at the Salar de Uyuni (southern Altiplano, Bolivia) and the Salinas Grandes (northern Puna, Argentina) during July 2009 and 2010, thus giving us a unique opportunity to learn about these phenomena. The dust storms occurred during a long drought period affecting the area. The effects of these dust events were observed at three Argentinean cities (La Calderilla near Salta City, Marcos Juárez, and Buenos Aires) located downwind from the main sources, where in turn dust samples were obtained. This offered a unique opportunity to examine the chemistry, particle size, transport/deposition fluxes, and concentrations of wind-blown dust and also to test the performance of transport models. Along with dust characterization, we also characterized the chemical and textural fingerprint of sediment from several potential PAP dust sources.

[6] Paleo-climatic records indicate that the environmental conditions of the PAP have changed significantly in the past [Seltzer et al., 2003]. Interest in the climate of the PAP has grown in recent decades because its variability has a strong impact on the availability of water resources over this region and the adjacent lowlands [Garreaud et al., 2003] and because of its links with continental-scale and hemispheric-scale atmospheric circulation [Zhou and Lau, 1998]. Because wind-borne minerals are strongly linked with atmosphere dynamics, the characterization of present-day PAP dust and its potential sources may also be useful for the interpretation of paleo-records preserved on the Argentine loess, Antarctic ice cores, and Southern Ocean marine sediments.

[7] This work is structured as follows. In section 2, we describe the main environmental characteristics of the PAP.
Section 3 details how samples were obtained and the methodologies used for their characterization, with a brief description of the Hybrid Single Particle Lagrangian Integrated Trajectory (HYSPLIT) model and the CALIPSO satellite products. In section 4, the different results are described, and in section 5, the results are conceptually integrated and discussed.

\section{Description of the Environmental Settings of the PAP}

[8] The PAP is a high elevated basin ( $4000 \mathrm{~m}$ a.s.l) located in the central portion of the Andes (see insert in Figure 1a) and is, after the Tibetean Plateau, the second largest plateau in the world, being over $1000 \mathrm{~km}$ long and $200 \mathrm{~km}$ wide. The area consists of extensive, internally drained depocenters flanked by $\mathrm{N}-\mathrm{S}$ oriented mountain ranges, often between 5000 and $6000 \mathrm{~m}$ elevation [Strecker et al., 2007]. The basins contain continental evaporites and volcanic and clastic deposits [Jordan and Alonso, 1987]. Mid-Tertiary contraction in this region has produced the formation of closed depocenters, now located within the plateau. The region contains very large salt beds including the Salar of Uyuni $\left(\sim 10,000 \mathrm{~km}^{2}\right)$ in Bolivia and the Salinas Grandes $\left(\sim 200 \mathrm{~km}^{2}\right)$ in Argentina.

[9] Modern mean annual temperature at the Salar de Uyuni is $5^{\circ} \mathrm{C}$, mean annual precipitation is about $150 \mathrm{~mm} \mathrm{yr}^{-1}$, and potential evapotranspiration exceeds precipitation $(\sim 1200$ $\mathrm{mm} \mathrm{yr}^{-1}$ ) [Fritz et al., 2004]. The South American Summer Monsoon (SASM) [Zhou and Lau, 1998] promotes intense convective storms supplying about $80 \%$ of precipitation in the austral summer (November to March). Westerly winds prevailing in middle and upper troposphere cause extreme dry conditions from May to October [Garreaud et al., 2009]. The main driver determining increase/decrease of moisture in the PAP area is an intensification of the SASM, but the mechanism of this is not yet fully understood (see detailed discussion in Strecker et al. [2007]). Briefly, the Central Andes block westbound moisture-bearing winds, leading to humid eastern sides and aridity within the PAP. The main source of precipitation is associated with Atlantic moisture coming from the Amazon and moisture related to the South Atlantic Convergence Zone during the summer [Garreaud et al., 2003]. In addition, the area is dominated by a subtropical high-pressure region (Bolivian High) with atmospheric subsidence. This promotes extremely arid conditions between about $15^{\circ} \mathrm{S}$ and $27^{\circ} \mathrm{S}$ comparable to the deserts at the same latitudes in western Africa and Australia [Strecker et al., 2007]. During the summer, a low-level atmospheric low-pressure system (NW Argentinean low) develops on the eastern slope of the Andes and interacts with the Bolivian High, which attracts moisture from the Amazon lowland [Vera et al., 2006]. This is possible in part because during the summer months the subtropical westerly jet stream weakens reaching its southernmost position. During winter, the interannual seasonal change in the tropospheric temperature gradient between low latitude and midlatitude promotes a stronger subtropical westerly jet stream that reaches its northernmost position around $27^{\circ} \mathrm{S}$. This prevents the regional moisture from reaching the eastern flank of the Andes, thus promoting a dry winter climate over the PAP [Prohaska, 1976]. This pattern can be significantly modulated by El Niño and La Niña events, which are the major sources of interannual climate variability over much of South America. The meridional thermal gradient between the tropics 


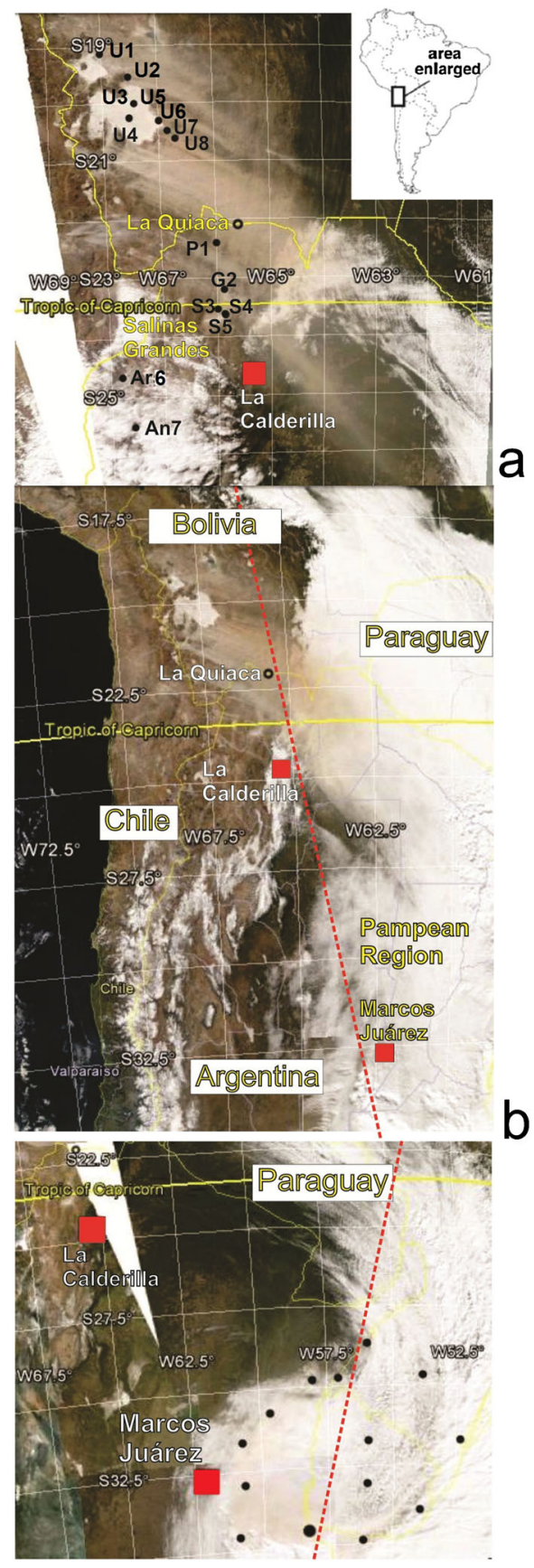

Figure 1. Dust plumes originating in Puna-Altiplano detected by MODIS on (a) 21 July 2009/Aqua 17:40 UTC, (b) 18 July 2010/Aqua 18:15 UTC, and (c) 19 July 2010/Terra 14:35 UTC (a likely situation was observed by Aqua at 17:15 UTC; not shown). Black dots (in Figure 1a) indicate the position of top soil samples and dust trapped at salar pans of Salar de Uyuni and Salinas Grandes. Red square indicates the position of dust monitoring station. In Figure 1c, dust (red) over clouds above southern south Brazil and Uruguay and near Buenos Aires City. Black dots (in Figure 1c) indicate the position of cities reporting rainfall on 19 July 2009. Dotted red line indicates the track of CALIPSO daytime (18:18 UTC) on 18 July 2010 (in Figure 1b) and nighttime (05:00 UTC) on 19 July 2010 (in Figure 1c) (see Figure 3). and subtropics becomes steeper during El Niño years. This promotes stronger westerly flow in the middle and upper troposphere over the Central Andes. Strengthened westerly flow reduces the incoming easterly moisture content, promoting wetter summers (El Niño) over southern Bolivia, northwestern Argentina, and the Pampas, and supporting more arid conditions over the PAP area. The opposite conditions occur during La Niña episodes [Vuille et al., 2000; Garreaud and Aceituno, 2001; Garreaud, 2009].

[10] The area under study was subjected to important climatic variation during the Late Quaternary. Large areas of the Altiplano were covered with paleolakes, indicating alternating cycles of dry/wet conditions [Sylvestre et al., 1999; Placzek et al., 2011]. However, there are debates among scientists about the main forcing factors determining these changes. Some authors [Baker et al., 2001; Fritz et al., 2004] found good correlation between periods of maximum insolation and increased availability of moisture, pointing to orbital control of the intensity of the SASM, although this pattern is not consistent when different temporal and spatial scales are considered [Markgraf and Seltzer, 2001], suggesting more complex mechanisms [Cook and Vizy, 2006].

[11] Similar to most of South America, during the last decade (2000-2009), the PAP area has experienced a continuous drought, as indicated by the net reduction of vegetation [Zhao and Running, 2010]. Moreover, an extremely strong and continuous drought has affected the area for at least 2000 years [Risacher and Fritz, 1991]. It is presently possible to observe in salars sequences of clean salt units (white) and salts contaminated with dust (brownish), which respectively recorded wet versus dry periods, providing long-term evidence of dust activity. Recent measurements of the Uyuni's albedo indicates that in May 2005 the ultraviolet (UV) radiation averaged $69 \%$. For the same month in 2008, this value fell to $59 \%$, and in May 2010 it fell to $43 \%$. This reduction was associated with increased dust deposition in the area [Zaratti et al., 2010].

[12] Particularly for the years 2009 and 2010, El Niño brought to the PAP area even drier conditions, contributing to the dust activity such as the one seen in the satellite images that motivated this study (Figure 1). The fine sediments entrained on these events were deposited at the end of the Pleistocene, when this region was filled with a lake covering a larger area including the Coipasa and Poopo basin [Servant and Fontes, 1978]. The sediments from the former lake, now located at the edge of the salar, serve as the source of the present-day dust activity [Prospero et al., 2002]. In the Puna, evidence indicates large basins of primary eolian origin of likely Pliocene/early Quaternary age. From about $18^{\circ} \mathrm{S}$ to $28^{\circ} \mathrm{S}$, sand dunes and wind-scoured ignimbrite ridges indicate a consistent NW-SE direction of likely late Pliocene to Pleistocene age [Goudie and Wells, 1995]. At the southern Puna, evidence of intense eolian deflation are indicated by the presence of exceptionally large and coarse grain-size wind ripples (reaching $43 \mathrm{~m}$ in wavelength and $2.3 \mathrm{~m}$ in amplitude) [Milana, 2009].

\section{Analysis Tools}

\subsection{Dust Collection}

[13] Dust samples were collected from two dust monitoring stations located at La Calderilla (near Salta City, 24.64 $\mathrm{S}$, 
$\left.65.55^{\circ} \mathrm{W}\right)$ and Marcos Juárez $\left(32.75^{\circ} \mathrm{S}, 62.13^{\circ} \mathrm{W}\right)$ (Figure $\left.1 \mathrm{~b}\right)$. La Calderilla station is located at the foot of the eastern slope of the Andes downwind from the PAP area situated $\sim 450$ $\mathrm{km}$ from Salar de Uyuni and $\sim 130 \mathrm{~km}$ from Salinas Grandes (Figure 1a). The Marcos Juárez station is $\sim 940 \mathrm{~km}$ SE from La Calderilla (Figure 1b). This station is located in a dust cross-corridor and depositional area (the Pampas) and is suited for monitoring dust activity in this region and the frequent dust storm outbreaks originating from Patagonia and the PAP.

[14] Each site was equipped with a $40 \mathrm{~cm}$ deep, inverted epoxy-coated fiberglass pyramidal receptacle $(\mathrm{CP})$ with a $0.25 \mathrm{~cm}^{2}$ collecting surface suited to measure vertical fluxes [Orange et al., 1990; Gaiero et al., 2003; Goossens and Rajot, 2008; Skonieczny et al., 2011]. An isokinetic modified Wilson and Cooke (MWAC) sampler [Wilson and Cooke, 1980] was used to measure dust horizontal fluxes and estimate dust concentrations [Warren et al., 2007] (Table 1). Both traps are passive collectors, and they trap particles at a height of 5 $\mathrm{m}$ to avoid collecting local saltation material. The efficiency of the MWAC is about $75-90 \%$ for wind speeds of $1-5 \mathrm{~m}$ $\mathrm{s}^{-1}$ (meter per second) [Goossens and Offer, 2000]. Because of its bad aerodynamic shape, the efficiency of the CP catcher is lower compared to MWAC collectors (1-25\%; Table 1) and decreases significantly with increased wind speed [Goossens and Rajot, 2008]. However, the CP collector is useful to obtain enough sediment mass to carry on different analytical tests [Rajot, 2001].

[15] The stations ran automatically for about 10-30 days, after which an operator collected the samples using a vacuum pump to filter (through dry or wet medium) and retain particles on a preweighed $0.45 \mu \mathrm{m}$ membrane. At the same time, the operator retrieved the data recorder from the weather station located on the same pole as the dust catchers. Fifteen/thirty minute average wind speeds were taken at a height of $5 \mathrm{~m}$ next to the MWAC collectors.

\subsection{Particle Size Analyses}

[16] In order to obtain information on the grain-size distribution of sediments representing PAP potential dust sources, 14 surface soil samples (top $5 \mathrm{~cm}$ ) were collected from areas that were identified by satellite images as important dust sources during different dust storms (Figure 1a). Samples were taken from intermountain closed basins representative of alluvial fans (around Salar de Coipasa, $19.42^{\circ} \mathrm{S}, 68.05^{\circ} \mathrm{W}$; Salar de Uyuni, $20.27^{\circ} \mathrm{S}, 67.59^{\circ} \mathrm{W}$; and Salinas Grandes, $\left.23.49^{\circ} \mathrm{S}, 65.85^{\circ} \mathrm{W}\right)$, and from the desiccated edge of the Pozuelo $\left(22.96^{\circ} \mathrm{S}, 65.87^{\circ} \mathrm{W}\right)$ and Guayatayoc $\left(23.35^{\circ} \mathrm{S}\right.$, $65.86^{\circ} \mathrm{W}$ ) lakes. Chunks of salt containing dust were collected at different points inside the Salar de Uyuni and Salinas Grandes. The sediments collected at the salar pans are used as representative of the grain-size distribution of eolian dust lifted from these source areas. About 100-200 g of this material was dissolved in $1 \mathrm{~L}$ of $\mathrm{Mil}^{\circledR}$ liQ water and then filtered through $0.45 \mu \mathrm{m}$ Millipore ${ }^{\circledR}$ filters. We eliminated the presence of organic matter by using $30 \% \mathrm{v} / \mathrm{v}_{2} \mathrm{O}_{2}$ analytical grade.

[17] In agreement with Stuut et al. [2005], we observed that the maximum grain size measured for bulk sediments trapped at the salar pan and dust samples trapped at the monitoring stations was $\sim 200 \mu \mathrm{m}$. Bulk top soil samples analyzed for grain-size distribution had been previously sieved through a $200 \mu \mathrm{m}$ sieves screen. At La Calderilla, grain-size distribution was analyzed on dust samples obtained with both CP and MWAC. However, for Marcos Juárez, the low mass availability determined that we use a composite dust sample made with dust from both collectors to characterize grain-size distribution and chemical analysis for this monitoring site.

[18] The grain size was measured by laser-diffraction size analysis using a Horiba LA-950 particle size analyzer. Samples were minimally dispersed to prevent the breaking up of aggregates. The precision (reproducibility) of the laserdiffraction particle sizer was tested by using mixtures of glass beads (NIST Traceable polydisperse particle standard PS202/ 3-30 $\mu \mathrm{m}$ and PS215/10-100 $\mu \mathrm{m}$, Whitehouse Scientific ${ }^{\circledR}$ ). For both runs (PS202, $n=6$ and PS215, $n=5$ ) the median (D50) was within 3\% certified nominal value, and the percentiles D10 and D90 were within 5\% of nominal values for the standards.

\subsection{Chemical Analyses of Dust and Soils}

[19] In order to learn about the provenance of dust obtained at the monitoring stations, collected airborne dust and top soil samples were chemically analyzed in terms of rare earth elements (REEs) (Table 2) [Gaiero et al., 2004; Wegner et al., 2011]. The REEs were analyzed at a commercial laboratory (Actlabs, Canada). Samples were digested by means of the alkaline fusion method $\left(\mathrm{Li}_{2} \mathrm{~B}_{4} \mathrm{O}_{7}, 1050^{\circ} \mathrm{C}\right.$, with $\mathrm{HNO}_{3}$

Table 1. Dust Fluxes and Concentrations at Marcos Juárez and La Calderilla (Salta)

\begin{tabular}{|c|c|c|c|c|c|}
\hline $\begin{array}{l}\text { Sampling Station } \\
\text { and Year }\end{array}$ & Date & $\begin{array}{l}\text { Vertical Fluxes } \\
\text { CP Collector } \\
\left(\mathrm{mg} \mathrm{m}^{-2} \mathrm{~d}^{-1}\right)\end{array}$ & $\begin{array}{l}\text { Horizontal Fluxes } \\
\text { MWAC Collector } \\
\quad\left(\mathrm{mg} \mathrm{m} \mathbf{~}^{-2} \mathbf{d}^{-1}\right)\end{array}$ & $\begin{array}{c}\text { Concentration } \\
\text { MWAC Collector } \\
\left(\mu \mathrm{g} \mathrm{m}^{-3}\right)\end{array}$ & $\begin{array}{c}\text { Type of } \\
\text { Deposition }\end{array}$ \\
\hline La Calderilla & Jun19-Jun30 & 78 & 289 & 2.8 & \multirow{4}{*}{ dry } \\
\hline \multirow[t]{2}{*}{2009} & Jun30-Jul22 & 88 & 2913 & 27.2 & \\
\hline & Jul22-Aug11 & 83 & 3955 & 37.1 & \\
\hline La Calderilla & Jun14-Jun24 & 3 & 346 & 1.2 & \\
\hline \multirow[t]{2}{*}{2010} & Jun24-Jul22 & 112 & 711 & 2.5 & \multirow[t]{2}{*}{ dry/snow } \\
\hline & Jul22-Aug15 & 53 & 900 & 2.4 & \\
\hline Marcos Juárez & Jun26-Jul06 & 183 & 870 & 5.4 & \multirow{3}{*}{ wet } \\
\hline \multirow[t]{2}{*}{2009} & Jul06-Jul22 & 97 & 1730 & 10.6 & \\
\hline & Jul22-Jul31 & 10 & 318 & 2.0 & \\
\hline Marcos Juárez & Jun04 -Jul13 & 22 & 250 & 1.4 & \multirow{3}{*}{ dry } \\
\hline \multirow[t]{2}{*}{2010} & Jul13 -Jul23 & 11 & 2940 & 17.6 & \\
\hline & Jul26-Aug05 & 5 & 670 & 4.3 & \\
\hline
\end{tabular}

Bold characters indicate dust sampling periods and fluxes measured during PAP dust events.

MWAC, modified Wilson and Cooke and CP, pyramidal receptacle. 
digestion) and analyzed by inductively coupled plasma mass spectrometry (ICP-MS; detection limit $=0.01 \mu \mathrm{g} \mathrm{l}^{-1}$; uncertainty based on 1 relative standard deviation of replicates was $2 \%$ ). The validity of the results was checked with NCS DC70014 (Brammer Standard) carried out along with sample analysis. At the Marcos Juárez site, only one dust sample was obtained during dust events with enough mass for carrying out REE analyses. Local people from Buenos Aires City provided us with a dust sample from the 2010 dust storm event. Seven top soils and one salar pan sample were analyzed from Uyuni and Coipasa (four samples) and Puna (four samples). Chemical analyses were run on the $<63 \mu \mathrm{m}$ grain size for top soil samples and on bulk for dust trapped at the salar pan.

\subsection{Simulation Tool}

[20] The HYSPLIT model simulates from simple trajectories to complex transport and dispersion of dust particles [Draxler and Rolph, 2003]. This model uses the meteorological fields from the National Centers for Environmental Prediction's (NCEP) Global Data Assimilation Scheme (GDAS) at 1 $\times$ degree resolution [Kanamitsu, 1989; Kalnay et al., 1996]. Calculation of advection and diffusion are made in a Langranian framework, while concentrations are calculated on a fixed grid [Draxler et al., 2001]. Dust emission is based on the threshold friction velocity approach by which surface roughness is correlated with soil properties. A threshold friction velocity of $28 \mathrm{~cm} \mathrm{~s}^{-1}$ is used. The equation for the emission of dust is $Q=0.01 \mathrm{U}^{* 4}$, where $Q$ is the emission rate and $\mathrm{U}^{*}$ is the friction velocity. The dust is assumed to be emitted at $10 \mathrm{~m}$ above ground level. When the local wind speed exceeds the threshold velocity for the soil type of that emission cell, the dust emission rate is computed [Escudero et al., 2006]. The model domain was set to the Southern Hemisphere $\left(0-90^{\circ} \mathrm{S}, 180^{\circ} \mathrm{W}\right.$ to $\left.180^{\circ} \mathrm{E}\right)$ at $1 \times 1$ degree resolution. The model allows the setting of a number of parameters such as mean grain size of the dust, intensity of the source, and duration of emission. The concentration grid for the model divided the atmosphere into eight layers from 0 to $10 \mathrm{~km}$.

[21] Dust plumes were also analyzed using the Cloud-Aerosol Lidar with Orthogonal Polarization (CALIOP) instrument on board the Cloud-Aerosol Lidar and Infrared Pathfinder Satellite Observation (CALIPSO) satellite [Winker et al., 2009]. Mass columnar and volume concentrations were derived from the backscattering coefficients measured by CALIOP. Level 1B (Validation Stage, version 3.01) backscattering coefficients $(532 \mathrm{~nm})$ were converted into extinction coefficients by assuming an $S$ ratio of 40 1/str (similar to the values reported in Omar et al. [2010] for Saharan dust) and then integrated over the column to obtain the aerosol optical depth (AOD). Then the AOD is converted to mass column concentration (units $\mathrm{g} \mathrm{m}^{-2}$ ) using a scaling relationship frequently used to relate the optical parameter to mass [Gassó and Hegg, 2003; Koren et al., 2006; Kokhanovsky et al., 2009]. Specifically, in this work we used the relationship defined in Koren et al. [2006] by which the mass concentration is computed as the product of the CALIPSO-derived aerosol depth at $532 \mathrm{~nm} \times 2.7 \mathrm{~g} \mathrm{~m}^{-2}$. While this simple approach does not consider a number of corrections (such as noise of signal, depletion of laser caused by multiple scattering, and difficulty in appropriately defining the boundaries of the dust cloud), it does provide a range of mass concentrations suitable for the comparisons shown here. The dust cloud dimensions were estimated directly from images generated from level $1 \mathrm{~B}$ data. In all cases reported here, dust cloud edges and respective layer thickness are estimates based on the contrast with the background. These values are reported as ranges because in many instances the dust cloud edges were too diffuse and/or mixed with a cloud top.

\section{Results}

\subsection{Meteorological and Satellite Observations of the Events}

[22] Satellite images (MODIS [http://lance-modis.eosdis. nasa.gov]) show two major dust storms occurring on 21 July 2009 and 18 July 2010 (MODIS morning and afternoon overpass). Both storms originated in the same sectors surrounding the Salar de Uyuni $\left(20.20^{\circ} \mathrm{S}, 67.50^{\circ} \mathrm{W}, 3650 \mathrm{~m}\right.$ a.s.l) and from the northern Puna sector $\left(23.17^{\circ} \mathrm{S}, 65.99^{\circ} \mathrm{W}\right.$, $3500 \mathrm{~m}$ a.s.1) (Figures 1a and 1b). Both dust events exhibited very similar features regarding the location of the sources and meteorological conditions. Wind direction was from the

Table 2. Rare Earth Elements Composition (in ppm) of Sediments From Potential Dust Source Areas in the Puna-Altiplano and Dust Collected at La Calderilla, Marcos Juárez and Buenos Aires

\begin{tabular}{|c|c|c|c|c|c|c|c|c|c|c|c|c|c|c|c|}
\hline & & $\mathrm{La}$ & $\mathrm{Ce}$ & $\operatorname{Pr}$ & $\mathrm{Nd}$ & $\mathrm{Sm}$ & $\mathrm{Eu}$ & Gd & $\mathrm{Tb}$ & Dy & Ho & $\mathrm{Er}$ & $\mathrm{Tm}$ & $\mathrm{Yb}$ & $\mathrm{Lu}$ \\
\hline Salar de Coipasa (alluvial fan) $(<63 \mu \mathrm{m})$ & $(\mathrm{U} 1)^{\mathrm{a}}$ & 50.6 & 99.4 & 10.5 & 38.6 & 6.9 & 1.4 & 5.3 & 0.8 & 4.0 & 0.8 & 2.2 & 0.34 & 2.2 & 0.39 \\
\hline Salar de Uyuni (alluvial fan) $(<63 \mu \mathrm{m})$ & (U2) & 48.4 & 96.7 & 10.4 & 39.9 & 6.8 & 1.2 & 4.8 & 0.7 & 3.3 & 0.6 & 1.7 & 0.25 & 1.6 & 0.25 \\
\hline Salar de Uyuni (salar pan) (bulk) & (U5) & 17.0 & 35.5 & 3.74 & 13.4 & 2.3 & 0.6 & 1.8 & 0.2 & 1.3 & 0.2 & 0.6 & 0.09 & 0.6 & 0.08 \\
\hline Salar de Uyuni (alluvial fan) $(<63 \mu \mathrm{m})$ & (U7) & 27.1 & 52.1 & 5.87 & 20.5 & 3.5 & 0.9 & 2.8 & 0.4 & 2.0 & 0.4 & 1.0 & 0.14 & 0.9 & 0.14 \\
\hline Salar Antofalla $(<63 \mu \mathrm{m})$ & (An7) & 35.6 & 74.0 & 8.35 & 30.0 & 5.7 & 1.3 & 5.4 & 0.8 & 4.6 & 0.9 & 2.7 & 0.43 & 2.9 & 0.44 \\
\hline Laguna de Pozuelo $(<63 \mu \mathrm{m})$ & $(\mathrm{P} 1)$ & 32.2 & 64.5 & 7.14 & 27.9 & 5.8 & 1.2 & 4.9 & 0.8 & 4.6 & 0.9 & 2.7 & 0.39 & 2.4 & 0.35 \\
\hline Salinas Grandes $(<63 \mu \mathrm{m})$ & (S4) & 37.0 & 72.8 & 8.02 & 30.6 & 6.1 & 1.2 & 5.1 & 0.9 & 5.2 & 1.1 & 3.2 & 0.46 & 2.9 & 0.43 \\
\hline Salar Arizaro Norte $(<63 \mu \mathrm{m})$ & (Ar6) & 36.3 & 78.6 & 8.82 & 32.6 & 6.1 & 1.5 & 5.2 & 0.8 & 4.1 & 0.8 & 2.3 & 0.35 & 2.4 & 0.36 \\
\hline Dust Marcos Juàrez ( 8 to 22 July 2009$)^{b}$ & & nd & 10.5 & 1.18 & 3.2 & 0.7 & 0.3 & 1.0 & 0.1 & 0.8 & 0.2 & 0.5 & nd & 0.6 & 0.12 \\
\hline Dust Marcos Juàrez (28 Jan to 8 Feb 2010) & & 30.2 & 73.9 & 7.86 & 29.4 & 5.8 & 1.4 & 6.0 & 0.9 & 4.9 & 1.0 & 3.1 & 0.43 & 2.8 & 0.52 \\
\hline Dust La Calderilla (30 Jun to 22 Jul 2009) ${ }^{b}$ & & 41.3 & 90.5 & 9.45 & 36.8 & 7.3 & 1.5 & 6.6 & 0.9 & 5.5 & 1.1 & 3.1 & 0.44 & 3.0 & 0.54 \\
\hline Dust La Calderilla (22 Jan to 17 Feb 2010) & & 28.3 & 70.8 & 7.21 & 25.1 & 5.5 & 1.1 & 5.3 & 0.7 & 4.7 & 1.0 & 2.7 & 0.40 & 2.8 & 0.45 \\
\hline Dust La Calderilla (18 Mar to 5 Apr 2010) & & 24.3 & 67.0 & 6.97 & 24.0 & 5.7 & 1.2 & 4.9 & 0.8 & 4.6 & 0.9 & 2.9 & 0.41 & 2.7 & 0.49 \\
\hline Dust La Calderilla (24 Jun to 22 Jul 2010) & & 37.3 & 83.0 & 8.89 & 32.9 & 6.6 & 1.4 & 6.1 & 0.9 & 5.5 & 1.1 & 3.2 & 0.47 & 3.1 & 0.53 \\
\hline Dust Buenos Aires (19 Jul 2010) & & 35.5 & 70.6 & 7.49 & 28.5 & 5.4 & 1.1 & 4.6 & 0.8 & 4.2 & 0.9 & 2.3 & 0.33 & 2.5 & 0.42 \\
\hline
\end{tabular}

${ }^{\mathrm{a}}$ See sample position in Figure 1.

${ }^{\mathrm{b}}$ Samples collected at the monitoring sites during the period of occurrence of dust storms at the Puna-Altiplano.

nd, not detected. 
NW and advected eastward. In both cases, the dust cloud expanded above a large cloud deck extending several hundred kilometers from the sources to the SE. The presence of the clouds precluded the retrieval of aerosol properties from these events because clear sky conditions are required for the MODIS aerosol retrieval algorithm to operate. The satellite image reveals the location of the dust sources. Dust plumes can be directly traced to small salars and dry lakes. The largest volume of dust was produced from adjacent alluvial fans surrounding the Salar de Uyuni, showing a chain of discrete plumes with a front width over $350 \mathrm{~km}$ long (Figures 1a and 1b). The active regions were identified by the high-resolution MODIS images $(250 \mathrm{~m})$, and by using Google Earth we could estimate the area emitting dust over $11,300 \mathrm{~km}^{2}$.

[23] Because meteorological data are not available for Uyuni City (closest city to the salar), we used information from La Quiaca City $\left(22.18^{\circ} \mathrm{S}, 65.55^{\circ} \mathrm{W}, 3460 \mathrm{~m}\right.$ a.s.l), located about $220 \mathrm{~km}$ downwind from Uyuni and clearly impacted by the dust storms (Figures 1a and 1b). La Quiaca is at approximately the same height as Uyuni, and the topography between the two localities is dominated by a flat plateau extending $50 \mathrm{~km}$ east of Uyuni and $50 \mathrm{~km}$ west of La Quiaca. Equidistant between both locations, there is a ridge with an elevation of $\sim 1000 \mathrm{~m}$ above surface. We observed that the assimilated wind speeds (GDAS database) used by HYSPLIT for the grid point corresponding to La Quiaca are comparatively lower but highly correlated to similar data obtained by the Argentine Weather Bureau (Servicio Meterologico Nacional [SMN]) at the surface station (Figure 2). In addition, by analyzing conditions several days before and during the dust events, we found that the assimilated wind speeds that drive HYSPLIT for the grid point corresponding to La Quiaca have a significant correlation with the mean assimilated wind speeds for four different grid points representing emission sources from Uyuni $\left(r^{2}=0.818, p<0.05, n=33\right.$ for 2009 and $r^{2}=0.701, p<0.05, n=29$ for 2010; see also Figure 2). Therefore, the surface station data from La Quiaca could be used as representative of the meteorological conditions found in Uyuni and to determine the onset and offset of the dust storms. Among the standard meteorological variables, the SMN at La Quiaca also monitors visibility conditions, which quantitatively measure the sky turbidity (visibility), indicating the presence of precipitation, haze, smoke, dust, etc. In general, "dust activity" is reported when visibility is about 5 $\mathrm{km}$, and "dust storm" is indicated when visibility is from less than $5 \mathrm{~km}$ down to $0.1 \mathrm{~km}$. For this study, visibility information is used to get independent confirmation of dust activity and duration of the event [Gassó et al., 2010].

\subsubsection{The 21 July 2009 Dust Event}

[24] During the entire month of July 2009, hourly meteorological data from La Quiaca reported a total of $16 \mathrm{~h}$ of dust activity (visibility $>5 \mathrm{~km}$ ) and $17 \mathrm{~h}$ of dust storm (visibility range $5-0.1 \mathrm{~km}$ ). The longest and most significant dust activity occurred on 21 July. At 5:00 UTC (local time $=U T C-3 \mathrm{~h}$ ), La Quiaca station reported normal conditions with visibility of $20 \mathrm{~km}$ and hourly mean wind speeds $(m \mathrm{WS})$ of $2.5 \mathrm{~m} \mathrm{~s}^{-1}$. One hour later (6:00 UTC), the reports indicated dust activity with $m \mathrm{WS}$ of around $6.5 \mathrm{~m} \mathrm{~s}^{-1}$ and visibility of $10 \mathrm{~km}$. Dust storm conditions (visibility $<5 \mathrm{~km}$ ) were reported at 11:00 UTC, with $m \mathrm{WS}$ at $19.2 \mathrm{~m} \mathrm{~s}^{-1}$ (Figure 2a). Assuming a similar hourly mean wind velocity at the source (e.g., $19.2 \mathrm{~m} \mathrm{~s}^{-1}$ ) and the distance from La Quiaca to the sources located SE
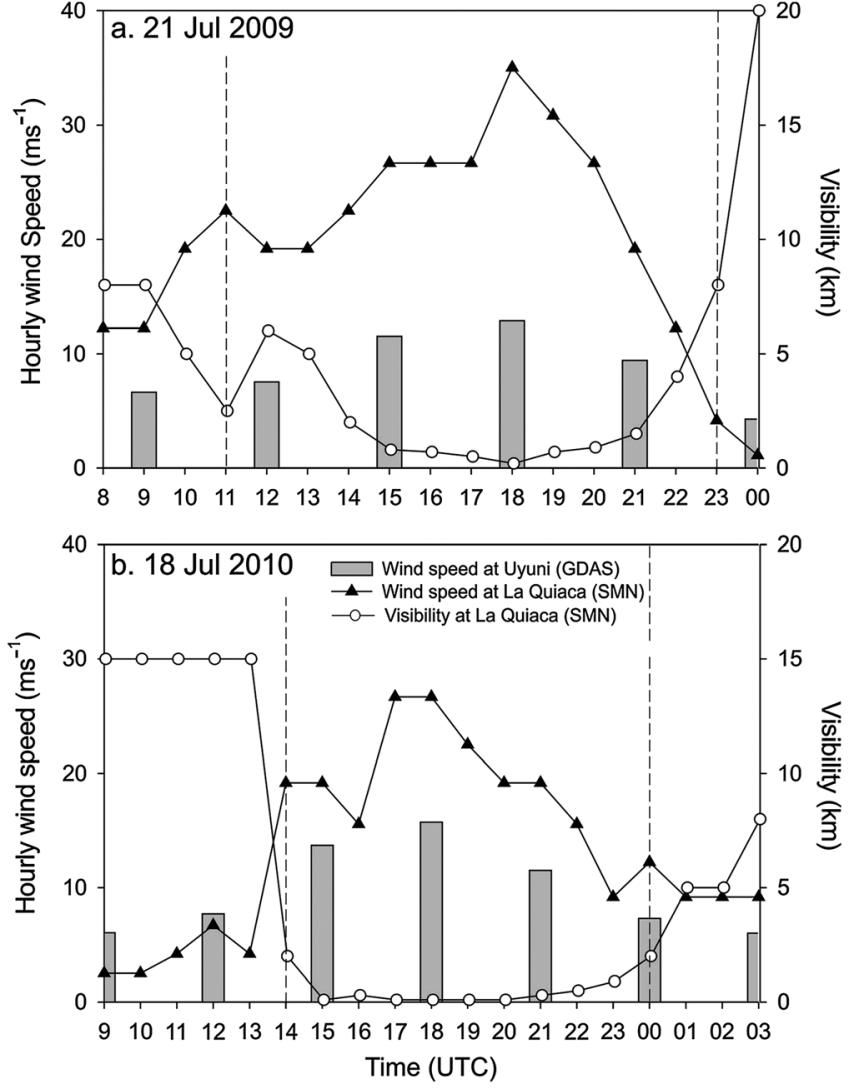

Figure 2. Meteorological data from the SMN at La Quiaca compared to $3 \mathrm{~h}$ mean wind speed obtained from the General Data Assimilation Scheme (GDAS) at $1 \times 1$ degree resolution for four different grid points representing emission sources from Uyuni. Dotted line indicates the beginning and end of dust storm reports according to SMN reports.

from the Salar $(\sim 250 \mathrm{~km})$, we estimate the beginning of the dust storm at Uyuni at 8:00 UTC. The last report for dust storm conditions was at 23:00 UTC, and dust activity ceased on 22 July at 00:00 UTC, when the La Quiaca station reported visibility of $8 \mathrm{~km}$ and $m \mathrm{WS}$ of $4.2 \mathrm{~m} \mathrm{~s}^{-1}$. Thus, dust activity lasted for about $18 \mathrm{~h}$, and dust storm conditions lasted about $12 \mathrm{~h}$. Dust plumes from this event were detected by MODIS (Figure 1a, Aqua 17:40 UTC), capturing just about the peak of the storm intensity when La Quiaca station reported visibility of $0.5-0.7 \mathrm{~km}$ and $m \mathrm{WS}$ over $27 \mathrm{~m} \mathrm{~s}^{-1}$. Only $1 \mathrm{~h}$ later, the $m \mathrm{WS}$ reached its maximum $\left(35 \mathrm{~m} \mathrm{~s}^{-1}\right)$, with very poor visibility $(0.2 \mathrm{~km})$ (Figure $2 \mathrm{a})$.

[25] On 21 July 2009, from 13:30 to 14:30 UTC, La Calderilla station recorded the arrival of a dry air mass from the west with an abrupt change in relative humidity from $40 \%$ to $14 \%$ and wind speed from 5 to $8 \mathrm{~m} \mathrm{~s}^{-1}$. The SMN at Salta airport $(\sim 10 \mathrm{~km}$ south from La Calderilla) reported dust activity from 15:00 UTC to 21:00 UTC with "dust storm" conditions for $4 \mathrm{~h}$ (16:00-20:00 UTC). Wind direction remained from the west, and winds averaged 27.7 $\mathrm{m} \mathrm{s}^{-1}$ (30 min intervals), with peaks of $38 \mathrm{~m} \mathrm{~s}^{-1}$. The SMN reported the lowest visibility at 19:00 UTC with 2 $\mathrm{km}$ visibility. On 21 July, the Marcos Juárez monitoring station recorded an increase in wind speed associated to the arrival of a polar front (wind direction from the SW). At 4:00 UTC until 23:00 UTC, the SMN station at Marcos 
Juárez reported low visibility associated with rainfall (average rainfall for this day, $15 \mathrm{~mm}$ ). On 22 July, the wind was still blowing from the SW, visibility was normal (20 $\mathrm{km}$ ), and no reduced visibility caused by dust was reported. 4.1.2. The 18 July 2010 Dust Event

[26] At La Quiaca, total rainfalls for years 2008 and 2009 were similar to the historical mean annual precipitation (370 $\mathrm{mm}[\mathrm{SMN}])$. However, for 2010, this area had a 30\% drop in total precipitation (257 $\mathrm{mm}$ [SMN]). These conditions provided the setting for many observations of dust activity in July 2010, with a total of $31 \mathrm{~h}$ of dust activity and $44 \mathrm{~h}$ of dust storm, a much higher number of hours than July 2009.

[27] In agreement with the visibility data from La Quiaca, dust activity was visible in MODIS images in Uyuni on 15 , $16,17,18$, and 21 July. Moreover, $27 \mathrm{~h}$ of dust activity was reported for the period of 22 July to 15 August, during which $9 \mathrm{~h}$ were recorded as “dust storm”. On 17 July, La Quiaca reported $6 \mathrm{~h}$ of dust storm beginning at 17:00 UTC. Accordingly, modest dust plumes were observed by MODIS (Aqua, 17:30 UTC). On 18 July starting at 14:00 UTC, La Quiaca reported $10 \mathrm{~h}$ of dust storm, indicating a mean visibility of $\sim 0.35 \mathrm{~km}$ and $m$ WS of $19.3 \mathrm{~ms}^{-1}$ during this period (Figure 2b). Using similar parameters to the 2009 event, we estimate the beginning of the dust storm at Uyuni at $\sim 11: 00$ UTC. The morning and afternoon passages of MODIS (18 July 2010, Terra/13:55 UTC and Aqua/18:15 UTC) show a dust storm (Figure 1b), detecting just about the peak of the event as indicated by the minimum visibility recorded at La Quiaca (Figure 2b). The last report with dust activity was on 19 July at 00:00 UTC, when visibility was again $2 \mathrm{~km}$, suggesting that the whole event lasted for about $10 \mathrm{~h}$.

[28] Because of snow and rainfall at Salta airport, the SMN reported low visibility from 15 July (15:00 UTC) until 18 July
(16:00 UTC). Low visibility was reported throughout the day, with values around $10 \mathrm{~km}$, fluctuating wind speeds (1-3.5 m $\mathrm{s}^{-1}$ ), and erratic wind direction. Unlike the 2009 dust event, the 2010 event was unnoticed at the Salta meteorological station. Comparatively, meteorological data indicated higher humidity and lower mean wind speed for 18 July. Like the 2009 dust event, during the evening hours of 18 July, the Marcos Juárez station recorded the arrival of an air mass from the SW. On the day after, wind gusts over $15 \mathrm{~m} \mathrm{~s}^{-1}$ from the SW were measured at the site. According to the SMN, no rainfall and no dust activity was observed during the whole dust sampling period (13-23 July; Table 1). Notably, while the visibility observations in La Quiaca SMN site agreed with those of the MODIS and CALIPSO detectors, the visibility observations in the Marcos Juárez SMN site do not report dust activity, whereas CALIPSO and the in situ sampler indicated the opposite (see sections 4.2 and 4.3). While there can be a number of reasons for this discrepancy, it is clear that sole reliance on one set of observations cannot be conclusive.

\subsection{Space-Based Estimations of Dust Emission and Concentration}

[29] Almost coinciding with the MODIS overpass on 18 July 2010, CALIPSO (18:18 UTC) profiled the PAP dust plume. The CALIOP instrument provided information on the location and vertical distribution of the dust plume near La Quiaca and Marcos Juárez (Figures $1 \mathrm{~b}$ and $3 \mathrm{a}$ ). Near La Quiaca, CALIPSO indicated a dust cloud with a base approximately at $5.0 \mathrm{~km}$ a.s.1., a top at $8.0 \mathrm{~km}$ a.s.l, and thickness ranging from 1.8 to $3.6 \mathrm{~km}$. Based on these thicknesses, the mean columnar concentration along the track was estimated to be $1.61-2.032 \mathrm{~g} \mathrm{~m}^{-2}$, which represents a dust concentration of $564 \mu \mathrm{g} \mathrm{m}^{-3}$ (for a thickness of $3.6 \mathrm{~km}$ ) to $913 \mu \mathrm{g} \mathrm{m}^{-3}$ (for a
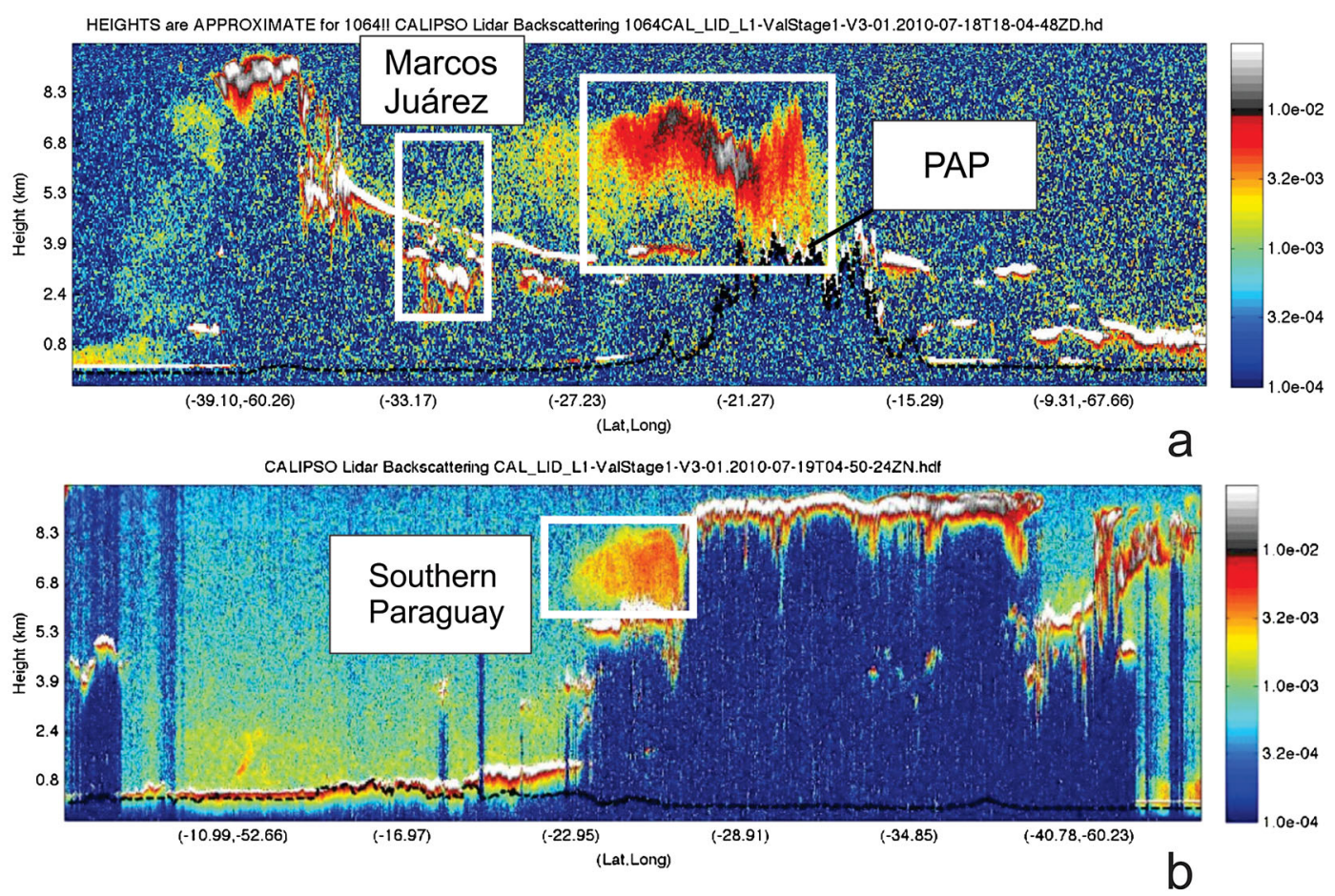

Figure 3. Backscattering profile showing dust plumes (indicated by white square) detected by CALIPSO (a) over the Puna-Altiplano and Marcos Juárez for 18 July 2010 (daytime) and (b) over Southern Paraguay on 19 July 2010 (nighttime). 
thickness of $1.8 \mathrm{~km}$ ). The CALIPSO profile cut through the dust cloud perpendicularly, and it provided an ideal crosssection suitable for a flow estimation. The length of the cross section is estimated as $\sim 250 \mathrm{~km}$; assuming an $m \mathrm{WS}$ of 10.7 $\mathrm{m} \mathrm{s}^{-1}$ (according to the GDAS database; Figure 2b) or 19.3 $\mathrm{m} \mathrm{s}^{-1}$ (according to La Quiaca measurements) during the 10 $\mathrm{h}$ that the SMN reported a dust storm, the emission strength could be estimated to be $\sim 4.4-5.4$ or $\sim 7.9-9.8 \mathrm{t} \mathrm{s}^{-1}$ (tons per second), depending on the wind speed used for the calculations. It is worth noting that wind speeds from the SMN coincide with estimations of the jet stream wind speed from ERA-40 reanalyses (1979-2001) (Uppala, 2005), indicating values for this area of 15-25 m s${ }^{-1}$ [Archer and Caldeira, 2008]. Estimations for the $10 \mathrm{~h}$ of dust emission indicate that $\sim 180$ or $320 \mathrm{kt}$ of sediments were exported from the PAP in one single event, which represents an emission flux of about $14-17$ or $25-31 \mathrm{t} \mathrm{km}^{-2}$. These numbers match the lower range estimated for dust storm emissions at one of the world's greatest source regions, the Bodélé depression in northern Chad [Ben-Ami et al., 2010].

[30] Over the Marcos Juárez site, CALIPSO detected a dust cloud but at much lower concentrations, located above $5 \mathrm{~km}$ and with an estimated thickness of 870-960 m (Figure 3a). However, HYSPLIT simulations (see section 4.6) and the distance from Marcos Juárez to the PAP $(\sim 1000-1300 \mathrm{~km})$ preclude a possible origin associated with the 18 July event, and this dust cloud is probably associated with previous dust activity observed on 15, 16, or 17 July 2010 (see section 4.1.2).

[31] Satellite images of 18 and 19 July 2010 show dust plumes close to the PAP and over clouds in northwestern Argentina (Figure 1b); $24 \mathrm{~h}$ later, the dust cloud was over the Pampas, Uruguay, and southern Paraguay and southern Brazil (19 July, Terra/14:35 UTC and Aqua/17:15 UTC; the former is shown in Figure 1c). During the earlier hours of 19 July ( 05:00 UTC), the nighttime overpass of CALIPSO detected the same dust cloud over southern Paraguay at a height of $\sim 7.0 \mathrm{~km}$ a.s.l. and $\sim 900 \mathrm{~km}$ north of Buenos Aires City $\left(38.81^{\circ} \mathrm{S}, 58.38^{\circ} \mathrm{W}\right)$. The dust cloud is on top of a convective system and is most likely mixed with the clouds underneath. The detected portion of the dust cloud is estimated to be $1.8-2.3 \mathrm{~km}$ thick. Estimations of the mean columnar dust concentration along the track range from 0.57 (thickness $1.8 \mathrm{~km}$ ) to $1.03 \mathrm{~g} \mathrm{~m}^{-2}$ (thickness $2.3 \mathrm{~km}$ ), and the estimated average dust concentration is $\sim 280-436 \mu \mathrm{g} \mathrm{m}^{-3}$, depending on the assumed thickness. These values indicate that after traveling $\sim 1300 \mathrm{~km}$, the dust plume concentration was reduced $\sim 50 \%$ compared to concentrations estimated near the sources.

[32] As mentioned before, the arrival of cold air masses from the south, mixed with the more humid air masses from the northwest, promoted the development of abundant rainfall over many sectors of central Argentina. During the morning time of 19 July, the rain washed down dust, and "red rain" was reported in many Argentinean and Uruguayan cities (Figure 1c). The red residue left by the rain was notable enough that it was reported in several newspapers in Buenos Aires City, where building roofs and backyard decks were covered by a thin layer of red sediment. On 20 and 21 July 2010, a set of satellite instruments (MODIS, OMI, CALIOP) detected dust over the Atlantic ocean, indicating that the PAP material was not completely removed by rain over the continent.

\subsection{Surface-Measured Dust Fluxes and Concentrations}

[33] Table 1 shows dust deposition fluxes and concentrations recorded during the sampling periods covering the dust events. These data are then compared with similar data from sampling periods preceding and following the dust events. Although background dust concentrations are significant, both monitoring stations recorded an increase of about 2 to 12 times in dust concentration during the storm periods (Table 2). Notably, these values are comparable to deposition fluxes estimated during large Sahara dust storms recorded on the coast of Senegal using similar methods [Skonieczny et al., 2011].

[34] The dust plume of 2009 reached the La Calderilla site (confirmed by SMN visibility observations), showing increased dust concentration but relatively low dust deposition. The low deposition measurement during the dust event is not surprising because the CP catcher has low sampling efficiency under high wind speeds [Goossens and Rajot, 2008; Skonieczny et al., 2011]. In addition, during turbulent flow conditions (wind gusts were over $27 \mathrm{~m} \mathrm{~s}^{-1}$ ), dust sedimentation caused by vertical mixing is reduced [Goossens, 2008]. During the unnoticed 18 July 2010 dust event, the La Calderilla station recorded a relatively calm day, and data for this period indicate a significant increase in dust deposition (probably induced by snow, as indicated by the SMN) (Table 1), with only slight increases in dust concentration.

[35] Downwind, the Marcos Juárez station recorded an increase in dust concentrations for both events. Wet dust deposition played a sizable role during the 2009 event because of the presence of rainfall. Later it will be shown that the increased dust concentration observed at the Marcos Juárez station in the 2009 event contained a mixture of sources including the PAP area. In the 2010 event, the low deposition fluxes at Marcos Juárez contrast with the substantial raininduced dust deposition observed in some nearby Pampean localities (see section 4.2). In contrast, the high dust concentration is in agreement with the strong wind gusts indicated for this day (see section 4.1.2), which in turn could prevent deposition. Concentration data from sampling periods preceding and following this event were very low (Table 2), suggesting that most of the concentration for the period between 13 and 23 July 2010 is a consequence of the July 2010 events. This is also supported by the CALIPSO observations over this area (see section 4.2).

\subsection{Grain-Size Distributions of Surface Soils and Dust}

[36] Dust storm samples from the monitoring sites show a well-sorted unimodal grain-size distribution, a known attribute of wind-blown sediments [Krumbein and Pettijohn, 1938; Stuut et al., 2005] and indicative of a single distant source [McTainsh et al., 1997] (Figure 4). At the Marcos Juárez station, composite dust samples show a unimodal grain-size distribution of around $11 \mu \mathrm{m}$. Dust samples from La Calderilla are also well sorted but are coarsely skewed, showing median modes of $\sim 12.0-14.0 \mu \mathrm{m}$. The dust sample obtained at Buenos Aires City also has a modal size of 14.1 $\mu \mathrm{m}$, similar to dust collected at La Calderilla (1300 km away). These results are similar to the modal sizes reported in a number of studies evaluating Saharan dust [Goudie and Middleton, 2006; Stuut et al., 2005; Skonieczny et al., 2011].

[37] Notably, dust samples obtained in both dust storms have different mode values and shape distributions compared 


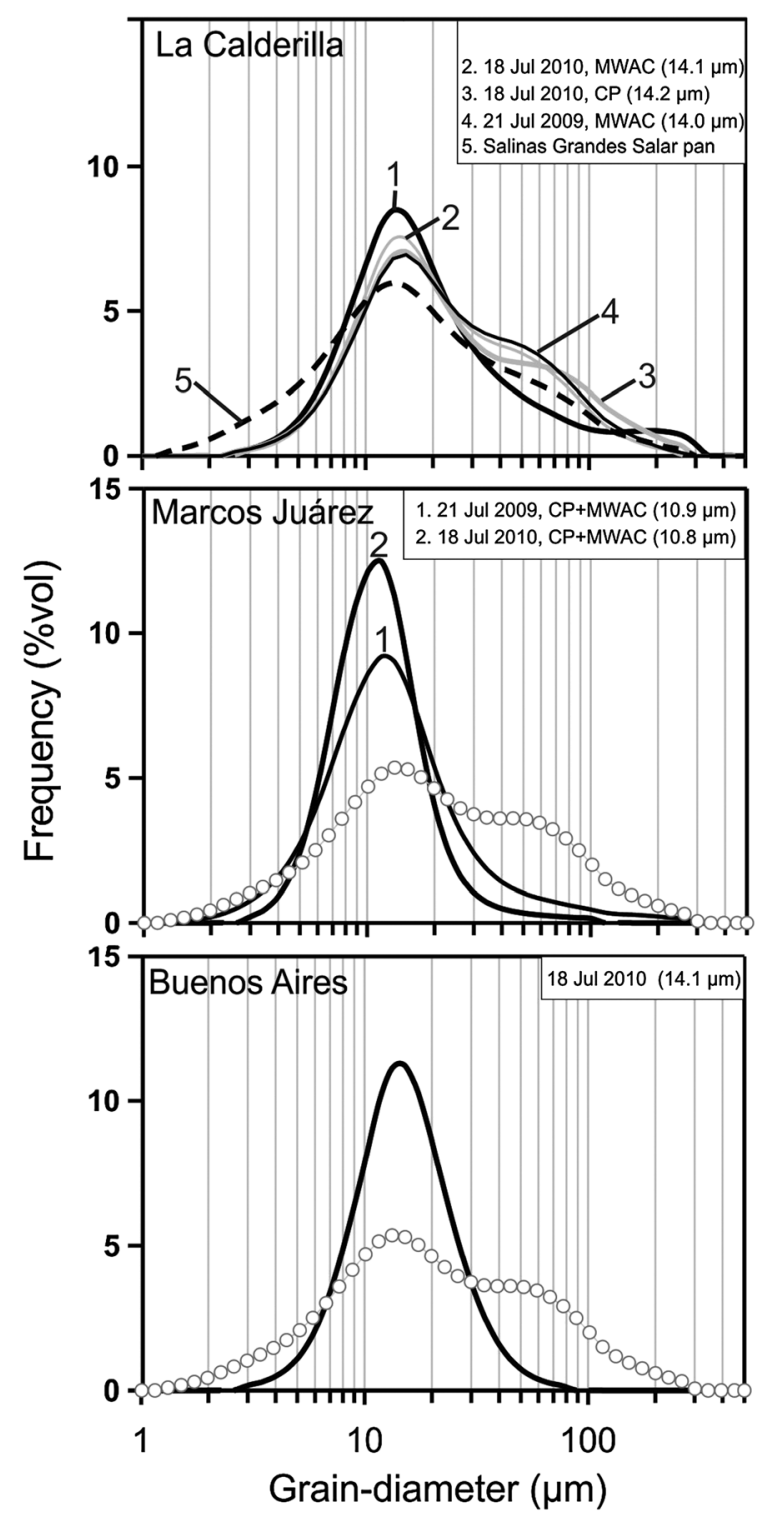

Figure 4. Grain-size distribution of dust samples obtained at three Argentine localities during dust events originating in the Puna-Altiplano. Numbers in brackets represent modal grain size. Open dots represent grain-size distribution of a mix of $50 \%$ grain-size distribution for a dust sample from the Uyuni salar pan and $50 \%$ dust sample from Salinas Grandes salar pan (see Figure 6).

to dust samples obtained before and after the events (Figure 5). The fact that the sampling periods for before, during, and after the dust event are about the same lengths $(\sim 10-30$ days $)$ strongly suggests that the observed dust flux increase during the event can be attributed to the few hours of dust deposition and that the contribution of additional background dust was minimal within the period. At La Calderilla, samples obtained during periods of storm events have a higher mean radius compared to samples obtained during non-dust activity periods (Figures $5 \mathrm{~b}$ and 5d). Similarly, a larger mean particle size is observed for a dust sample collected between 22 July and 15 August 2010, when dust storms were also reported (see section 4.1.2.). Figures $5 \mathrm{~b}$ and $5 \mathrm{~d}$ also indicate that the finer mode grain size corresponds to samples collected during wet periods or periods with relative lower dust activity, probably representing the background of dust load of the local atmosphere. Particle size data for samples from Marcos Juárez indicate a different situation (Figures 5a and 5c). Finer mode dust is deposited during dust event periods, which point to a dominant long-range transport, contrasting with a dominance of coarser mode observed for non-dust sampling periods, pointing to dominant local sources. The 2009 dust sample is coarsely skewed compared to the 2010 dust sample, suggesting a possible contamination with local dust sources, as also indicated by chemical data (see section 4.5).

[38] A comparison between grain-size distributions from samples collected at the surface of the PAP area is shown in Figure 6. Mean median size (D50) for samples from the Uyuni area $(\mathrm{D} 50=28.7 \mu \mathrm{m})$ shows coarser mode particles compared to samples representing the northern Puna (D50 $=11.4 \mu \mathrm{m}$ ). Several unimodal grain-size distributions are observed in the Puna sediments (modes at 10 and $20 \mu \mathrm{m}$ ), while sediments from Uyuni have comparable and well-defined bimodal grain-size distributions (modes at 11-15 and 50-70 $\mu \mathrm{m}$ ). The mean grain size observed for the Uyuni salar pan samples $(\sim 50 \mu \mathrm{m})$ contrast with similar samples from the Salinas Grandes $(\sim 28 \mu \mathrm{m})$. Figure 4 indicates that particle size distribution of dust storm samples from La Calderilla have a similar mode and shape compared to sediment samples from the salar pan of Salinas Grandes (Puna). For the case of dust storm samples collected at distal sites (i.e., Marcos Juárez and Buenos Aires), their grain-size distributions match well with the fine mode obtained by mixing $50 \%$ of Puna and $50 \%$ of Uyuni mean grain-size distribution of the salar pan samples (Figure 4).

\subsection{Chemical Signature of Dust Collected at the Monitoring Sites}

[39] The REE composition of eolian dust is known to be a good fingerprint of the parental rocks in source areas. REE patterns found for the PAP surface sediments are clearly different from the mean pattern representing Patagonian dust [Gaiero et al., 2004] (Figure 7a). Furthermore, both PAP source areas have distinct REE signatures, e.g., sediments from Uyuni show light REE enrichment, while sediments from Puna have a more crustal-like composition, with a flat REE pattern.

[40] According to grain-size data, REE data also indicate that different sources seem to contribute dust to La Calderilla (Figure $7 b$ ). Dust samples obtained during the rainy season (January-April) have unlike REE signatures compared to dust collected during dust storm periods, which have a dominantly northern Puna-like signature. The increase in dust concentration recorded at Marcos Juárez during July 2009 (see section 4.3) contains a non-PAP signature, suggesting a supply of local emissions (Figure 7c), as also suggested by grain-size data. For example, the MODIS image for 22 July 2009 (Terra 14:00 UTC), shows dust activity $\sim 350 \mathrm{~km} \mathrm{SW}$ of Marcos Juárez City and advecting in the direction of the site. REE composition of the dust sample at the Marcos Juárez site confirms a non-single PAP signature. Thus, the influence of the Patagonian REE fingerprint could be the consequence of the influx of dust from a nearby source (for example, Vicuña Mackenna, $33.92^{\circ} \mathrm{S}, 64.38^{\circ} \mathrm{W}$, one of the active sources observed in the same MODIS image). As indicated in Figure 7d, a good approximation to the Marcos Juárez dust sample composition is achieved by combining $50 \%$ of the 


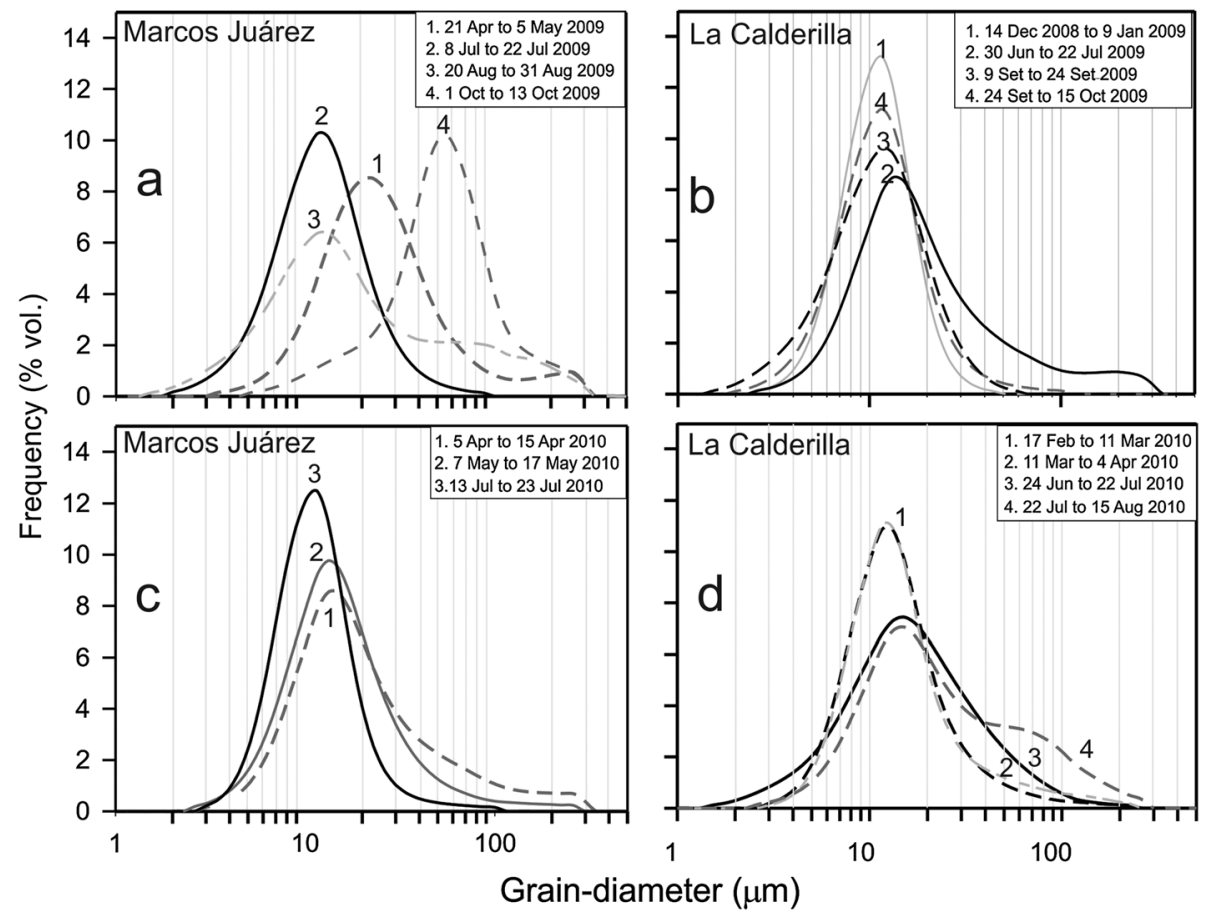

Figure 5. Grain-size distribution of dust samples obtained at Marcos Juárez and La Calderilla during sampling periods with no dust storm reports, compared to dust samples acquired during dust storm periods (black lines). All samples were obtained using pyramidal receptacles (CP) except the composite dust storm samples from Marcos Juárez (see text).

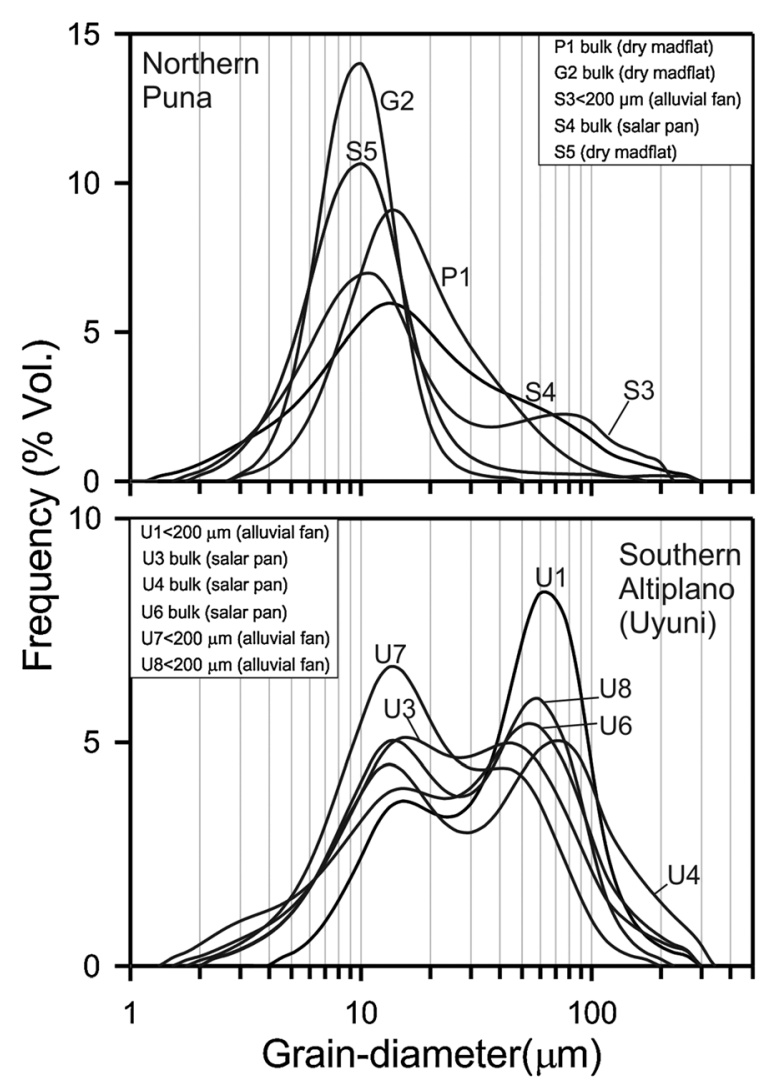

Figure 6. Grain-size distribution of sediment samples from potential dust sources located in the Puna-Altiplano Plateau. See references in Figure 1.
REE composition of Buenos Aires dust with $50 \%$ of the REE composition of the Vicuña Mackenna top soil sample [Gaiero et al., 2004].

[41] Interestingly, although satellite images show a large dust cloud originating in the Uyuni area (Figures 1a and 1b), REE patterns indicate that dust deposited at Buenos Aires City has a mixed provenance with slight dominance of Puna origin (60\%) compared to the Altiplano sources (40\%) (Figure 7c). This suggests that there was dust activity from additional sources nonactive at the time of the satellite pass.

\subsection{Modeling PAP Dust Plumes}

[42] Forward runs with the HYSPLIT model were carried out at five different height levels $(0,1000,3500,5000$, and $8000 \mathrm{~m}$ a.g.l. [meters above ground level]) in order to track the dust plume evolution, its areal coverage, timing of arrival, and transport patterns during the 2010 dust event. We set the model with a mean dust emission rate of $\sim 32 \mathrm{kt} \mathrm{h}^{-1}$ using $m \mathrm{WS}$ from the SMN at La Quiaca (see section 4.2). By using this emission rate, HYSPLIT outputs are indicative of an upper estimation of dust deposition/concentration during the event. We also constrained the model by particle size and by a mass factor of the emitted dust (a parameter that can be set within HYSPLIT) based on the measured mean grain-size distribution for dust trapped in the salt bed of Salar de Uyuni $(n=3$, mean particle size for the coarse mode of $64 \mu \mathrm{m}$ and mean particle size for the fine mode of $16 \mu \mathrm{m}$ with mass factors of $56 \%$ and $44 \%$, respectively). Mass density for dust was assumed to be $2650 \mathrm{~kg} \mathrm{~m}^{-3}$ [Li et al., 2008], and the model was run with the dry and wet deposition option turned on using default settings. Based on section 4.1.2, the model was initialized at 11:00 UTC, and emission duration was constrained by surface 


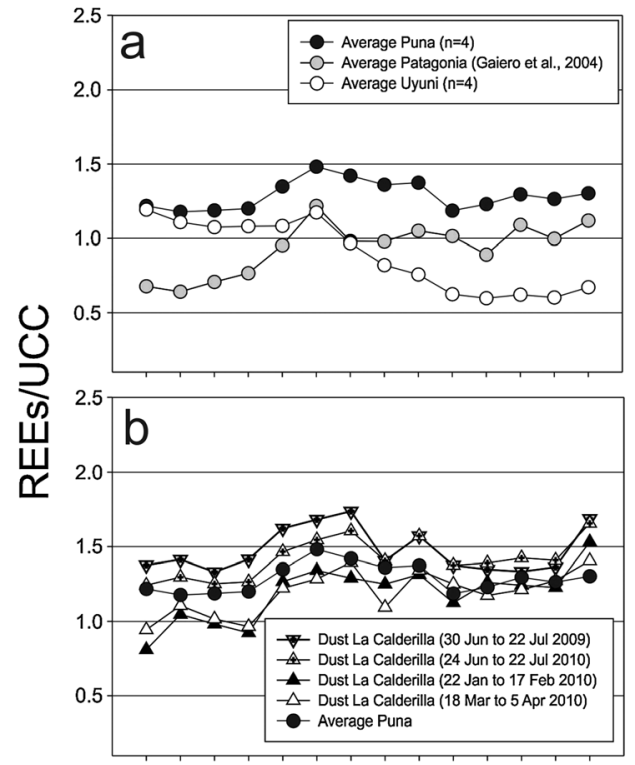

La Ce Pr Nd Sm Eu Gd Tb Dy Ho Er Tm Yb Lu

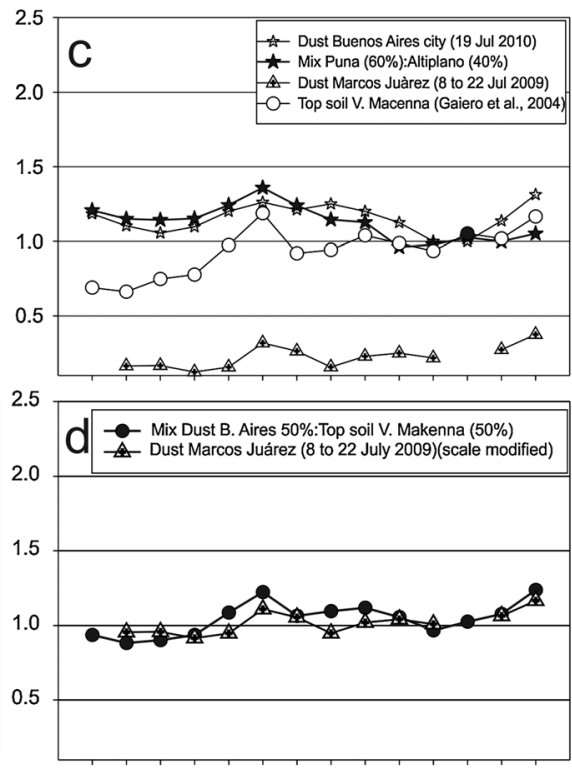

La Ce Pr Nd Sm Eu Gd Tb Dy Ho Er Tm Yb Lu

Figure 7. Upper crust composition (UCC)-normalized rare earth element (REE) patterns for (a) samples from the Puna-Altiplano Plateau, (b) dust trapped at La Calderilla, and (c) dust deposited at Buenos Aires City and trapped at Marcos Juárez. (d) Comparison between the Marcos Juárez dust composition with a composition obtained by mixing dust from Buenos Aires with a top soil sample from the area where dust entrainment was observed in July 2009 near the Marcos Juárez monitoring site [UCC; Taylor and McLennan, 1995].

visibility data. As can be seen in Figures $1 \mathrm{a}$ and $1 \mathrm{~b}$, dust emission was initialized from the seven largest selected sources of dust at $10 \mathrm{~m}$ a.g.l.

[43] Figure 8 shows normalized total deposition and total columnar concentration for $36 \mathrm{~h}$ after the 18 July 2010 event. In this figure, maximum deposition/concentration values are represented by red, and minimum values are represented by green. The simulated deposition indicates that more than half of the total emitted dust mass was deposited near the sources and that over one third of the surface of Uruguay and about one third of the surface of Buenos Aires Province (including Buenos Aires City) received the highest deposition rates (red area in Figure 8a). HYSPLIT predicts significant depositions over most of Paraguay and Uruguay, the southern tip of Brazil, and northwest Buenos Aires Province in Argentina, which represents about one third of the total emitted dust (orange area, Figure 8a). The model also indicates that a significant proportion of PAP dust was deposited in the ocean off the Buenos Aires and the Patagonian coasts. The simulated total columnar concentration of the plume shows the leading edge with higher concentrations located over Buenos Aires City (Figure 8b). Noticeably, model outputs agree with MODIS observations and with "red rain" reported from Argentinean and Uruguayan cities (compare Figures $1 \mathrm{~b}$ and $1 \mathrm{c}$ with Figures $8 \mathrm{a}$ and $8 \mathrm{~b}$ ).

[44] Using similar parameters as for the 2010 event, model outputs for the 2009 event show that the simulated dust plume is mostly advected over Paraguay and southern Brazil and mostly exits to the Atlantic Ocean.

\section{Discussion}

[45] During the years 2009 and 2010, an extended drought associated with El Niño conditions promoted intense dust activity over the PAP. MODIS and CALIPSO satellites detected these events. Dust deposited at three sites downwind from the sources with simultaneous and collocated meteorological measurements was investigated in terms of its chemical and textural composition. The results and findings described in the previous sections can be summarized as follows:

[46] 1. Both dust events occurred during July (austral winter) when the intensification of the subtropical jet stream is at its maximum.

[47] 2. An analysis of meteorological data combined with satellite observations permitted the estimation of an upper limit of the dust emission rate $\left(25-31 \mathrm{t} \mathrm{km}^{-2}\right)$ produced at the PAP during a single dust storm.

[48] 3. Dust monitoring sites located close $(\sim 350 \mathrm{~km})$ and far away $(\sim 1300 \mathrm{~km})$ from the source areas captured both events, recording an increase in both dust fluxes and concentrations.

[49] 4. Evidence indicates that the dust plume on July 2010 traveled a minimum of $2000 \mathrm{~km}$ in less than $24 \mathrm{~h}$ with observed wet dust deposition in the Central Pampas.

[50] 5. At approximately similar distances from the source $(\sim 2000 \mathrm{~km})$, dry dust deposition has a finer grain size (mode $\sim 11 \mu \mathrm{m}$, Marcos Juárez) compared to wet dust deposition (mode $\sim 14 \mu \mathrm{m}$, Buenos Aires).

[51] 6. Dust deposited by rain over the Central Pampas had a mixed chemical composition, with an estimated $60 \%$ northern Puna component and 40\% southern Altiplano component.

[52] 7. Chemical data agree in pointing to the northern Puna as the main dust supplier to La Calderilla station and a mixed origin of dust reaching the Marcos Juárez station.

[53] 8. Forward modeling, initialized by observed dust sources and intensity for the 2010 event, places dust cloud distribution and deposition outputs in agreement with satellite and surface data. 


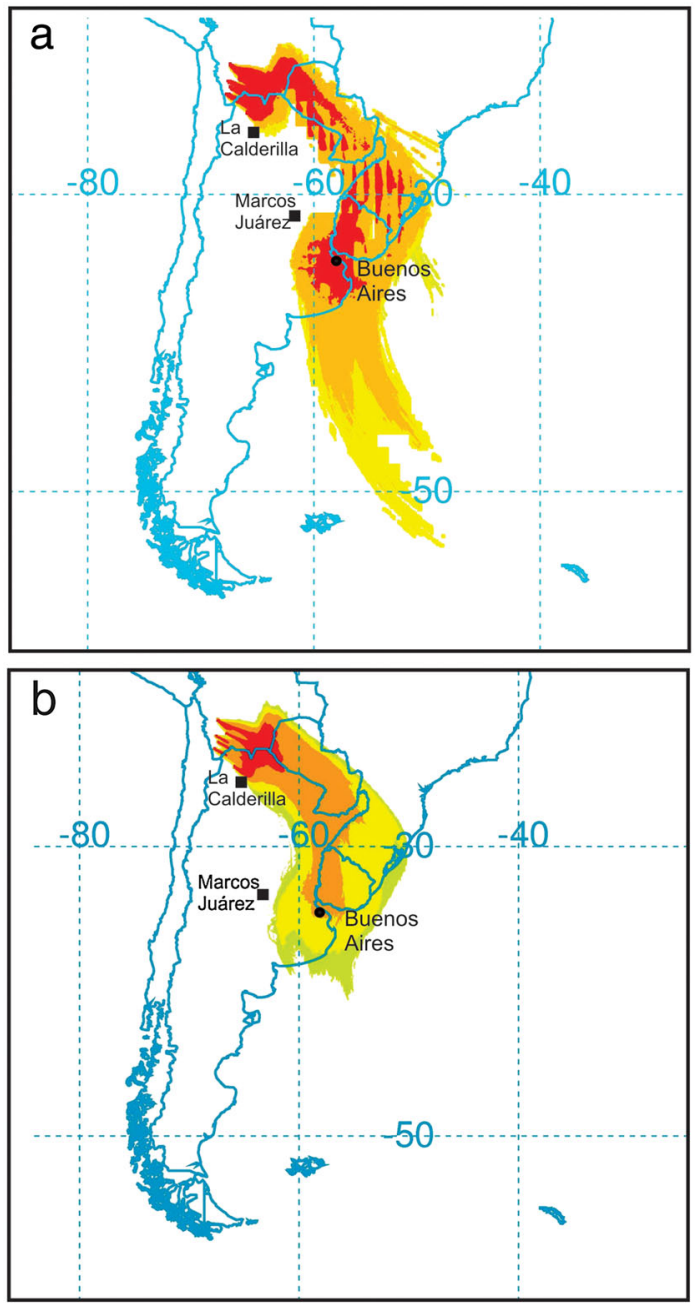

Figure 8. Hybrid Single Particle Lagrangian Integrated Trajectory (HYSPLIT) modeled deposition and concentration of the 18 July 2010 dust plume originating in the Puna-Altiplano plateau. (a) Normalized total dust deposition from 11:00 18 July to 23:00 19 July 2010 (UTC). (b) Normalized total columnar air concentration averaged from 0 to $8000 \mathrm{~m}$ a.g.l. integrated from 11:00 18 July to $23: 0019$ July 2010 (UTC). Red indicates maximum and green indicates minimum dust deposition/concentration values.

[54] 9. After a run of $36 \mathrm{~h}$, the model predicts that most of the emitted dust from PAP was deposited over the continent along a band from $2800 \mathrm{~km}$ long to $200-700 \mathrm{~km}$ wide.

[55] There are few studies for which field observations served to constrain and test models in this region of the world [Gassó et al., 2010; Johnson et al., 2011]. One of the important uncertainties in modeling dust is the lack of observationally based dust emissions from source regions and the threshold wind speed required to initiate deflation of surface sediments [Ginoux et al., 2001; Tegen et al., 2002]. According to visibility data and wind speed recorded by the SMN at La Quiaca, "dust activity" at the PAP was initially reported when wind speed was over $4.2-6.5 \mathrm{~m} \mathrm{~s}^{-1}$; "dust storm" was reported when wind velocity exceeded $19 \mathrm{~m} \mathrm{~s}^{-1}$. Although these data are hourly based and from a meteorological station distant from the sources, the latter figure could represent the specific threshold wind speed for a dust storm in the PAP area, which is similar to values of 11-20 $\mathrm{m} \mathrm{s}^{-1}$ found in the Gobi Desert [Laurent et al., 2005].

[56] CALIPSO showed that about $260 \mathrm{~km}$ away from the main dust sources, the highest concentration of the plume reached heights of $\sim 2.1 \mathrm{~km}$ above the PAP surface (i.e., more than $8000 \mathrm{~m}$ a.g.1.). Once aloft, dust plumes are transported by the westerly subtropical jet streams at a mean height of $7000 \mathrm{~m}$ a.s.l., and in about $24 \mathrm{~h}$ they can reach the Central Pampas. Surface analysis showed that particles had a mean grain size of $16 \mu \mathrm{m}$ when they reached this area. Surface data also show that when injected at the core of the jet stream, dust particles of up to $70 \mu \mathrm{m}$ could be transported over long distances $(>2000 \mathrm{~km})$ from the source. Large particles have been also noted in long-range transport of Saharan dust to the Caribbean area [Reid et al., 2003].

[57] Because of the low efficiency of the passive dust traps and the long time of sampling periods, dust fluxes and concentration data obtained in this work should be considered as minimum values and are representative of the concentrations found at near-surface air masses. At the Marcos Juárez site, the interpretation of field data is not straightforward because the site is located in a cross-corridor of air masses receiving an influence from the main dust sources of southern South America. Model results as well as MODIS images show little impact of PAP plumes over this monitoring site. However, CALIPSO observations as well as horizontal fluxes/concentrations and textural/ chemical data of dust samples obtained during the dust storm time frame point to the influence of PAP storms over this site.

[58] We observed that both dust storms concurred with the outbreaks of polar fronts entering the Central Pampas. In the case of the 2009 event, the combination of MODIS images and chemical/textural data help us to deduce that the increased dust concentration at the Marcos Juárez site was caused in part by the input from a mixture of local and distant dust sources. In this case, the vertical fluxes are mostly dominated by very coarse locally produced dust, which is associated with the high dust deposition observed. However, the fine dust fraction originates mainly from the long transport from distal sources. These observations have implications for understanding the mechanism of Argentine loess deposition. Similar to the Chinese loess [Sun et al., 2004], the Argentine loess has a bimodal grain-size pattern [Smith et al., 2003]. The fine modal pattern we observe for modern PAP dust deposited on the Pampas (e.g., Marcos Juárez, Buenos Aires) is also observed for the average grain-size distribution of loess samples taken at different depths and localities in a N-S profile of Central Argentina [Smith et al., 2003]. This is in agreement with the fact that the silt fraction population of eolian particles is generally transported by surface winds in short suspension episodes and accumulates to form thick deposits in adjacent downwind areas [Tsoar and Pye, 1987; Pye, 1987; Sun et al., 2004]. As observed in this study, the fine-grain population can be dispersed over a wide altitudinal band and can be transported in upper level air masses. Depending on the type of deposition (wet or dry), fine dust could be deposited relatively closely, induced by rain (e.g., "red rain" over the Pampas), or transported long distances and deposited in the remote ocean or Antarctica.

[59] One important finding in this contribution is the individualization of the chemical signatures of PAP sediments 
and their distinction from the Patagonian chemical signature. New chemical data from PAP surface sediments and dust from monitoring stations support previous investigations suggesting a major role for this area as a dust supplier during glacialinterglacial periods [Gaiero, 2007; Delmonte et al., 2010; Maher et al., 2010]. This is also indicated in Figure 9 and suggests that most of the continental sediments deposited during glacial-interglacial periods in the Scotia Sea, Antarctica, and the Pampas have * Eu/Eu vs $\mathrm{Yb} / \mathrm{La}$ ratios explained mostly by a mix of Patagonian and northern Puna origin. Also, according to the data obtained in this study, the southern Altiplano could also play an important role in explaining the composition of these materials.

\section{Conclusions}

[60] This work combined chemical and textural analyses of surface soil and dust samples (potential dust sources/dust monitoring stations) with ground observations (meteorological data), satellite images, measurements (MODIS/CALIPSO), and model simulation (HYSPLIT), all of which have improved our understanding of the emission, transport, and deposition of eolian sediments emitted during dust storms produced in the subtropical high Puna-Altiplano deserts.

[61] The locations of the surface dust monitoring sites were suitable for deriving an estimate of the dust fluxes and for the interpretation of different aspect of these dust storms. Although passive collectors like the ones used in this study

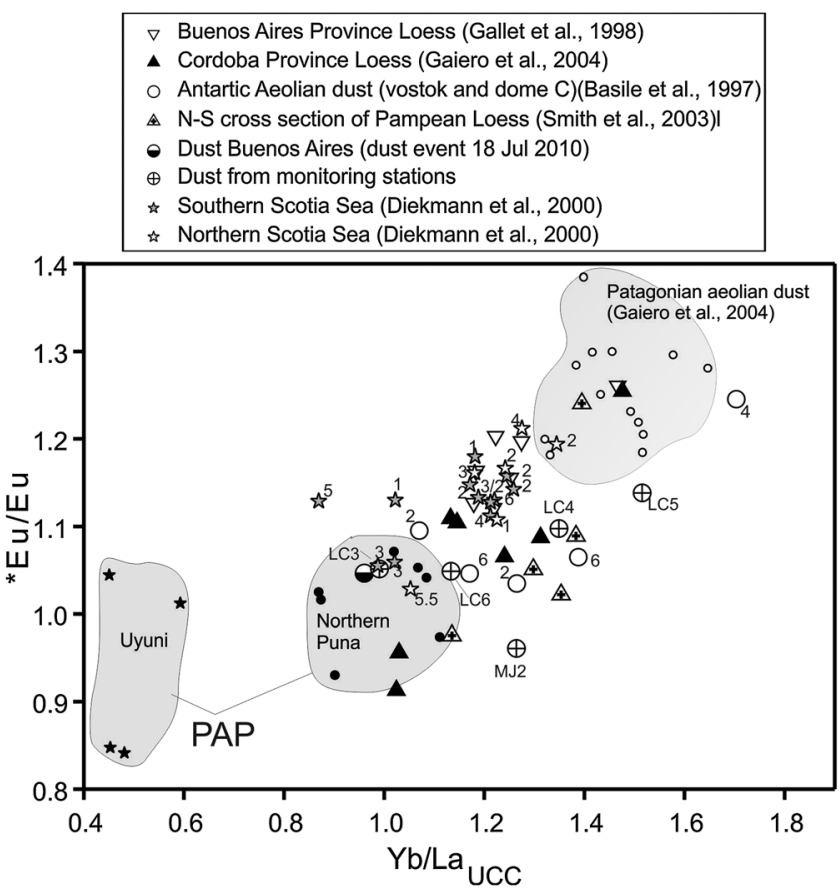

Figure 9. Relationship between $\mathrm{Eu}^{*}$ anomaly and $\mathrm{Yb} / \mathrm{La}$ for dust from monitoring sites (LC/La Calderilla and $\mathrm{MJ} /$ Marcos Juárez) and Buenos Aires City, dust from Dome C, sediment cores from the Scotia Sea, and loess from Buenos Aires and Cordoba provinces. Numbers close to the icons refer to "marine isotopic stages" (MIS). They are contrasted to shadowed areas corresponding to possible sources located in Patagonia and Puna-Altiplano. have low efficiency and time resolution, the long-term exposition (10-30 days) permitted us to collect enough dust mass for different type of analyses. Furthermore, such measurements are scarce in South America, and the flux estimates, grain size, and chemical data obtained in this study provide the required constraints for atmospheric transport models and dust deposition estimates in this area.

[62] The results reported here show that an important proportion of sediments from the PAP reach the Atlantic Ocean; a more detailed analysis of the geochemistry and mineralogy of this material will help us to determine the potential role of such sediments in ocean fertilization and whether they reach Antarctica.

[63] As indicated for southern South America, El Niño events provoke intense dry conditions over the PAP (increase deflation) and wet conditions over the lowland areas to the east (increase rainfall). This mechanism could have important implications for the interpretation of paleo-records, for example, the Argentinean loess, and could shed light on the characteristics of deposition. This interpretation is helped by the exploration of the chemical and textural composition of PAP sediments, which have a distinct latitudinal signature and are clearly different from the Patagonian chemical fingerprint. Moreover, the possibility of distinction between the chemical/textural signature of the northern Puna and that of the southern Altiplano in paleo-record archives (loess, ocean sediment cores, ice cores, etc.) could have significance for understanding the equatoward/poleward displacement of the subtropical westerly jet stream during past climatic cycles.

[64] Acknowledgments. The authors express their deep thanks to Mr. Mariano D'Alto, who kindly provided the Buenos Aires dust sample, and Florence Sylvestre, who provided the top soil sample from Coipasa. Ms. G. Torres and S. Bordese helped with lab activities. Mr. M. Hilario kindly assisted us with salar pan sampling within the Salar de Uyuni. We are indebted to the Servicio Meteorologico Nacional for the meteorological data. We also acknowledge the U.S. National Aeronautics and Space Administration and the National Oceanic and Atmospheric Administration for making the satellite data and modeling tools freely available. This work was financially supported by grants awarded to D.M.G.: Antorchas, IAI, the Weizmann Institute, SECyT/UNC, and FONCyT (PICT-0625).

\section{References}

Albani, S., N. Mahowald, B. Delmonte, V. Maggi, and G. Winckler (2011), Comparing modeled and observed changes in mineral dust transport and deposition to Antarctica between the Last Glacial Maximum and current climates, Clim. Dyn., 38, 1731-1755, doi:10.1007/s00382-011-1139-5.

Archer, C. L., and K. Caldeira (2008), Historical trends in the jet streams, Geophys. Res. Lett., 35, L08803, doi:10.1029/2008GL033614.

Baker, P. A., C. A. Rigsby, G. O. Seltzer, S. C. Fritzs, R. K. Lowenstein, N.P. Bacher, and C. Veliz (2001), Tropical climate changes at millennial and orbital timescales on the Bolivian Altiplano, Nature, 409, 698-701.

Basile, I., F. E. Grousset, M. Revel, J. R. Petit, P. E. Biscaye, and N. I. Barkov (1997), Patagonian origin of glacial dust deposited in East Antarctica (Vostok and Dome C) during glacial stages 2, 4 and 6, Earth Planet. Sci. Lett., 146, 573-589.

Ben-Ami, Y., I. Koren, Y. Rudich, P. Artaxo, S. T. Martin, and M. O. Andreae (2010), Transport of North African dust from the Bodélé depression to the Amazon Basin: A case study, Atmos. Chem. Phys., doi:10, 10.5194/acp-10-7533-2010.

Cook, K. H., and E. K. Vizy (2006), South American climate during the last glacial maximum: Delayed onset of the South American monsoon, J. Geophys. Res., 111, D02110, doi:10.1029/2005JD005980.

Delmonte, B., P. Andersson, H. Schoberg, M. Hansson, J. R. Petit, R. Delmas, D. Gaiero, V. Maggi, and M. Frezzotti (2010), Geographic provenance of Aeolian dust in East Antarctica during Pleistocene glaciations: Preliminary results from Talos Dome and comparison with East Antarctic and new Andean ice core data, Quaternary Sci. Rev., 29, 256-264.

Diekmann, B., B. G. Kuhn, V. Rachold, A. Abelmann, U. Brathauer, D. K. Fütterer, R. Gersonde, and H. Grobe (2000), Terrigenous sediment 
supply in the Scotia Sea (Southern Ocean): Response to Late Quaternary ice dynamics in Patagonia and the Antarctic Peninsula, Palaeogeogr. Palaeoclimatol. Palaeoecol., 162, 357-387.

Draxler, R. R., and G. D Rolph (2003), HYSPLIT (HYbrid Single-Particle Lagrangian Integrated Trajectory), Model access via NOAA ARL READY Website, NOAA Air Resources Laboratory, Silver Spring, MD. Available at http://www.arl.noaa.gov/ready/hysplit4.html

Draxler, R. R., D. A. Gillette, J. S. Kirkpatrick, and J. Heller (2001), Estimating PM10 air concentrations from dust storms in Iraq, Kuwait, and Saudi Arabia, Atmos. Environ., 35, 4315-4330.

Escudero, M., A. Stein, R. R. Draxler, X. Querol, A. Alastuey, S. Castillo, and A. Avila (2006), Determination of the contribution of northern Africa dust source areas to PM10 concentrations over the central Iberian Peninsula using the Hybrid Single-Particle Lagrangian Integrated Trajectory model (HYSPLIT) model, J. Geophys. Res., 111, D06210, doi:10.1029/ 2005JD006395.

Fritz, S. C., P. A. Baker, T. Lowenstein, G. O. Seltzer, C. A. Rigsby, G. S. Dwyer, P. M. Tapia, K. K. Arnold, T. L. Ku, and S. Luo (2004), Hydrologic variation during the last 170000 years in the Southern Hemisphere tropics of South America, Quaternary Res., 61, 95-104.

Gaiero, D. M. (2007), Dust provenance in Antarctic ice during glacial periods: From where in southern South America?, Geophys. Res. Lett., 34 L17707, doi:10.1029/2007GL030520.

Gaiero, D. M., J. L. Probst, P. J. Depetris, S. M. Bidart, and L. Leleyter (2003), Iron and other transition metals in Patagonian riverborne and windborne materials: Geochemical control and transport to the southern South Atlantic Ocean, Geochim. Cosmochim. Acta, 67(19), 3603-3623.

Gaiero, D. M., P. J. Depetris, J. L. Probst, S. M. Bidart, and L. Leleyter (2004), The signature of river-and wind-borne materials exported from Patagonia to the southern latitudes: A view from REEs and implications for paleoclimatic interpretations, Earth Planet. Sci. Lett., 219(3-4), 357-376.

Gallet, S., B. Jahn, B. Van Vliet Lanoë, A. Dia, and E. Rossello (1998), Loess geochemistry and its implications for particle origin and composition of the upper continental crust, Earth Planet. Sci. Lett., 156, 157-172.

Garreaud, R. D. (2009), The Andes climate and weather, Adv. Geosciences, 7, 1-9.

Garreaud, R. D., and P. Aceituno (2001), Interannual rainfall variability over the South American Altiplano, J. Climate, 14, 2779-2789.

Garreaud, R. D., M. Vuille, and A. C. Clement (2003), The climate of the Altiplano: Observed current conditions and mechanisms of past changes, Palaeogeol. Palaeoclim. Palaeoecol., 194, 5-22.

Garreaud, R. D., M. Vuille, R. Compagnucci, and J. Marengo (2009), Present-day South American climate, Palaeogeogr. Palaeoclimatol. Palaeoecol., 281, 180-195.

Gassó, S., and D. A. Hegg (2003), On the retrieval of columnar aeroso mass and CCN concentration by MODIS, J. Geophys. Res., 108(D1), 4010, doi:10.1029/2002JD002382.

Gassó, S., A. Stein, F. Marino, E. Castellano, R. Udisti, and J. Ceratto (2010), A combined observational and modeling approach to study modern dust transport from the Patagonia desert to East Antarctica, Atmos. Chem. Phys., 10, 8287-8303, doi:10.5194/acp-10-8287-2010.

Ginoux, P., M. Chin, I. Tegen, J. M. Prospero, B. Holben, O. Dubovik, and S. J. Lin (2001), Sources and distributions of dust aerosols simulated with the GOCART model, J. Geophys. Res., 106, 20,255-20,273, doi:10.1029/ 2000JD000053.

Goossens, D. (2008), Relationships between horizontal transport flux and vertical deposition flux during dry deposition of atmospheric dust particles, J. Geophys. Res., 113, F02S13, 13, doi:10.1029/2007JF000775.

Goossens, D., and Z. Offer (2000), Wind tunnel and field calibration of six aeolian dust samplers, Atm. Environ., 34, 1043-1057.

Goossens, D., and J. L. Rajot (2008), Techniques to measure the dry aeolian deposition of dust in arid and semi-arid landscapes: A comparative study in Sahelian West Africa, Earth Surf. Processes Landforms, 33, 178-195, doi:10.1002/esp.1533

Goudie, A. S., and G. L. Wells (1995). The nature, distribution and formation of pans in arid zones, Earth Sci. Rev., 38, 1-69.

Goudie, A. S., and N. J. Middleton (2006), Desert Dust in the Global System, Springer, Berlin.

Jickells, T. D., N. Mahowald, J. M. Prospero, A. J. Ridgwell, I. Tegen, and R. Torres (2005), Global iron connections between desert dust, ocean biogeochemistry, and climate, Science, 308, 67-71.

Johnson, M. S., N. Meskhidze, V. P. Kiliyanpilakkil, and S. Gassó (2011) Understanding the transport of Patagonian dust and its influence on marine biological activity in the South Atlantic Ocean, Atmos. Chem. Phys., 11, 2487-2502, doi:10.5194/acp-11-2487-2011.

Jordan, T. E., and R. N. Alonso (1987), Cenozoic stratigraphy and basin tectonics of the Andes mountains, $20^{\circ}-28^{\circ}$ South Latitude, Am. Assoc. Petrol. Geol. Bull., 71, 49-64.

Kalnay, E., M. Kanamitsu, and R. Kistler (1996), The NCEP/NCAR 40-year reanalysis project, Bull. Am. Meteorol. Soc., 77, 437-471.
Kanamitsu, M. (1989), Description of the NMC global data assimilation and forecast system, Weather Forecast., 4, 335-342.

Koch, D., G. A. Schmidt, and C. Field (2006), Sulfur, sea salt and radionuclide aerosols in GISS, ModelE, J. Geophys. Res., 111, D06206 doi:10.1029/2004JD005550.

Kokhanovsky, A. A., A. S. Prikhach, I. L. Katsev, and E. P. Zege (2009), Determination of particulate matter vertical columns using satellite observations, Atmos. Meas. Tech., 2, 327-335, doi:10.5194/amt-2-327-200.

Koren, I., Y. J. Kaufman, R. Washington, M. C. Todd, Y. Rudich, J. Vanderlei Martins, and D. Rosenfeld (2006), The Bodele depression: A single spot in the Sahara that provides most of the mineral dust to the Amazon forest, Environ. Res. Lett., 1, 014005

Krumbein, W. C., and F. J. Pettijohn (1938), Manual of Sedimentary Petrography, Appleton-Century-Crofts, New York, NY.

Laurent, B., B. Marticorena, G. Bergametti, P. Chazette, F. Maignan, and C. Schmechtig (2005), Simulation of the mineral dust emission frequencies from desert areas of China and Mongolia using an aerodynamic roughness length map derived from the POLDER/ADEOS 1 surface products, J. Geophys. Res., 110, D18S04, doi:10.1029/2004JD005013.

Li, F., P. Ginoux, and V. Ramaswamy (2008), Distribution, transport, and deposition of mineral dust in the Southern Ocean and Antarctica: Contribution of major sources, J. Geophys. Res., 113, D10207, doi:10.1029/ 2007JD009190.

Li, F., P. Ginoux, and V. Ramaswamy (2010), Transport of Patagonian dust to Antarctica, J. Geophys. Res., 115, D18217, doi:10.1029/ 2009JD012356

Liu, M., D. L. Westphal, S. Wang, A. Shimizu, N. Sugimoto, J. Zhou, and Y. Chen (2003), A high-resolution numerical study of the Asian dust storms of April 2001, J. Geophys. Res., 108(D23), 8653, doi:10.1029/ 2002JD003178.

Liu, Z., D. Liu, M. Vaughan, I. Uno, N. Sugimoto, C. Kittaka, C. Trepte, Z. Wang, C. Hostetler, and D. Winker (2008), Airborne dust distributions over the Tibetan Plateau and surrounding areas derived from the first yea of CALIPSO lidar observations, Atmos. Chem. Phys., 8, 5045-5060, doi:10.5194/acp-8-5045-2008.

Maher, B. A., J. M. Prospero, D. Mackie, D. Gaiero, P. P. Hesse, and Y. Balkanski (2010), Global connections between aeolian dust, climate and ocean biogeochemistry at the present day and at the last glacial maximum, Earth Sci. Rev., 99, 61-97, doi:10.1016/j.earscirev.2009.12.001.

Markgraf, V., and G.O. Seltzer (2001), Pole-equator-pole paleoclimates of the Americas integration: Toward the big picture, in Interhemispheric Climate Linkages, edited by V. Markgraf, Academic, San Diego, Calif., pp. 433-442.

Martin, J. H., W. W. Broenkow, S. E. Fitzwater, and R. M. Gordon (1990), Does iron really limit phytoplankton production in the offshore subarctic Pacific-yes, it does-a reply, Limnol. Oceanogr., 35(3), 775-777.

McTainsh, G. H., A. W. Lynch, and K. Tews (1997), Climatic controls upon dust storm occurrence in eastern Australia, J. Arid Environ., 39, 457-466. Milana, J.P. (2009), Largest wind ripples on Earth?, Geology, 37, 343-346, doi:10.1130/G25382A.1.

Miller, R. L., I. Tegen, and J. Perlwitz (2004), Surface radiative forcing by soil dust aerosols and the hydrologic cycle, J. Geophys. Res., 109, D04203, doi:10.1029/2003JD004085.

Omar, A., Z. Liu, M. Vaughan, K. Thornhill, C. Kittaka, S. Ismail, Y. X. $\mathrm{Hu}$, G. Chen, K. Powell, D. Winker, C. Trepte, E. Winstead, and B. Anderson (2010), Extinction-to-backscatter ratios of Saharan dust layers derived from in situ measurements and CALIPSO overflights during NAMMA, J. Geophys. Res., 115, D24217, doi:10.1029/2010JD014223.

Orange, D., J. Y. Gac, J. L. Probst, and D. Tanre (1990), Mesure du dépôt au sol des aérosol désertiques. Une méthode simple de prélèvement: Le capteur pyramidal, $C$. Acad Sci Paris, 311(2), 167-172.

Placzek C. J., J. Quade, and P. J. Patchett (2011), Isotopic tracers of paleohydrologic change in large lakes of the Bolivian Altiplano, Quaternary Res., 75, 231-244.

Prohaska, F. J. (1976), Climates of Central and South America, in World Survey of Climatology, A. Schwerdtfeger, editor, Elsevier, New York, NY, pp. 13-72.

Prospero, J. M., P. Ginoux, O. Torres, S. E. Nicholson, and T. E. Gill (2002), Environmental characterization of global sources of atmospheric soil dust identified with the NIMBUS 7 Total Ozone Mapping Spectrometer (TOMS) absorbing aerosol product, Rev. Geophys., 40(1), 1002, doi:10.1029/2000RG000095.

Pye, K. (1987), Aeolian Dust and Dust Deposits, Academic, London.

Rajot, J. L. (2001), Wind blown sediment mass budget of Sahelian village land units in Niger, Bull. Soc. Geol. Fr., 172(5), 523-531, doi:10.2113/ 172.5.523

Ravi, S., P. D'Odorico, D. D. Breshears, J. P. Field, A. S. Goudie, T. E. Huxman, J. Li, G. S. Okin, R. J. Swap, A. D. Thomas, S. Van Pelt, J. J. Whicker, and T. M. Zobeck (2011), Aeolian processes and the biosphere, Rev. Geophys., 49, RG3001, doi:10.1029/2010RG000328. 


\section{GAIERO ET AL.: DUST STORMS FROM PUNA-ALTIPLANO DESERTS}

Reid, J. S., H. H. Jonsson, H. B. Maring, A. Smirnov, D. L. Savoie, S. S. Cliff, E. A. Reid, J. M. Livingston, M. M. Meier, O. Dubovik, and S. Tsay (2003), Comparison of size and morphological measurements of coarse mode dust particles from Africa, J. Geophys. Res., 108, 8593, doi:10.1029/2002JD002485.

Risacher, F., and B. Fritz (1991), Quaternary geochemical evolution of the salars of Uyuni and Coipasa, Central Altipiano, Bolivia, Chem. Geol., 90, 211-231

Seltzer, G., D. Rodbell and H. Wright (2003), Late-quaternary paleoclimates of the southern tropical Andes and adjacent regions, Palaeogeol. Palaeoclim. Palaeoecol., 194, 1-3.

Servant, M., and J. Fontes (1978), Les lacs quaternaires des hauts plateaux des Andes boliviennes. Premières interprétations paléoclimatiques, $\mathrm{Cah}$. ORSTOM, Sér. Géol., IO(I), 9-23.

Skonieczny, C., A. Bory, V. Bout-Roumazeilles, W. Abouchami, S. J. G. Galer X. Crosta, J. B. Stuut, I. Meyer, I. Chiapello, T. Podvin, B. Chatenet, A. Diallo, and T. Ndiaye (2011), The 7-13 March 2006 major Saharan outbreak: Multiproxy characterization of mineral dust deposited on the West African margin, J. Geophys. Res., 116, D18210, doi:10.1029/2011JD016173.

Smith, J., D. Vance, R. A. Kemp, C. Archer, P. Toms, M. King, and M. Zarate (2003), Isotopic constraints on the source of Argentinian loess with implications for atmospheric circulation and the provenance of Antarctic dust during recent glacial maxima, Earth Planet. Sci. Lett., 212(1-2), 181-196.

Sokolik, I. N., D. M. Winker, G. Bergametti, D. A. Gillette, G. Carmichael, Y. Kaufman, L. Gomes, L. Schuetz, and J. E. Penner (2001), Outstanding problems in quantifying the radiative impact of mineral dust, J. Geophys. Res., 106, 18015-18028.

Strecker, M. R., R. N. Alonso, B. Bookhagen, B. Carrapa, G. E. Hilley, E. R. Sobel, and M. H. Trauth (2007), Tectonics and climate of the southern central Andes, Annu. Rev, Earth Planet. Sci., 35, 747-787.

Stuut, J. B., M. Zabel, V. Ratmeyer, P. Helmke, E. Schefub, G. Lavik, and R. Schneider (2005), Provenance of present-day eolian dust collected off NW Africa, J. Geophys. Res., 110, D04202, doi:10.1029/2004JD005161.

Sun, D., B. Jan, D. K. Rea, Z. An, V. Jef, H. Lu, R. Su, and T. Liu (2004), Bimodal grain-size distribution of Chinese loess, and its palaeoclimatic implications, Catena, 55, 325-340.

Sylvestre, F., M. Servant, S. Servant-Vildary, C. Causse, M. Fournier, and J. P. Ybert (1999), Lake-level chronology on the Southern Bolivian Altiplano $\left(18^{\circ}-23^{\circ} \mathrm{S}\right)$ during late-glacial time and the Early Holocene, Quaternary Res., 51,54-66.

Taylor, S. R., and S. M. McLennan (1995), The geochemical evolution of the continental crust, Rev. Geophys., 33, 241-265.

Tegen, I., A. A. Lacis, and, I. Fung (1996), The influence of mineral aerosols from disturbed soils on the global aerosol radiation budget, Nature, 380, 419-422.
Tegen, I., S. P. Harrison, K. Kohfeld, I. C. Prentice, M. Coe, and M. Heimann (2002), Impact of vegetation and preferential source areas on global dust aerosol: Results from a model study, J. Geophys. Res., 107 (D21), 4576, doi:10.1029/2001JD000963.

Thomason, L. W., M. C. Pitts, and D. M. Winker (2007), CALIPSO observations of stratospheric aerosols: A preliminary assessment, Atmos. Chem. Phys., 7, 5283-5290.

Tsoar, H., and K. Pye (1987), Dust transport and the question of desert loess formation, Sedimentology, 34, 139-153.

Uppala S. M. (2005), The ERA-40 re-analysis, Q. J. R. Meteorol. Soc., 131, 2961-3012.

Vera, C., W. Higgins, J. Amador, T. Ambrizzi, and R. Garreaud (2006), A unified view of the American monsoon systems, J. Climate, 19, 4977-5000.

Vuille, M., R. S. Bradley, and F. Keimig (2000), Interannual climate variability in the Central Andes and its relation to tropical Pacific and Atlantic forcing, J. Geophys. Res., 105, 12447-12460, doi:10.1029/ 2000JD900134.

Warren, A., M. C. Chappell, C. Todd, N. Bristow, S. Drake, V. Engelstaedter, S. Martins, and R. Washington (2007), Dust-raising in the dustiest place on Earth, Geomorphology, 92, 25-37.

Wegner, A., P. Gabrielli, D. Wilhelms-Dick, U. Ruth, M. Kriews, P. De Deckker, C. Barbante, G. Cozzi, B. Delmonte, H. Fischer (2011) Rare earth elements from an ice core in the Atlantic sector of Antarctica indicate a dust provenance change at the end of the last deglaciation, Climate Past Discussions, 7(1), 601-633.

Winker, D. M., M. A. Vaughan, A. H. Omar, Y. Hu, K. A. Powell, Z. Liu, W. H. Hunt, and S. A. Young (2009), Overview of the CALIPSO mission and CALIOP data processing algorithms, J. Atmos. Oceanic Technol., 26, 2310-2323, doi:10.1175/2009JTECHA1281.1.

Wilson, S. I., and R. V. Cooke (1980), Wind Erosion in Soil Erosion, John Wiley \& Sons, New York, NY, pp. 217-251.

Zaratti, F., R. Forno, G. Gutierrez, R. Apaza, and F. Velarde (2010), Medidas de albedo en UV-B en el Salar de Uyuni, Rev. Boliviana Fís., $17,8-12$.

Zender, C. S., H. Bian, and D. Newman (2003), Mineral Dust Entrainment and Deposition (DEAD) model: Description and 1990s dust climatology, J. Geophys. Res., 108(D14), 4416, doi:10.1029/2002JD002775.

Zhao, M., and S. W. Running (2010), Drought-induced reduction in global terrestrial net primary production from 2000 to 2009, Science, 329, 940-943.

Zhou, J., and K. M. Lau (1998), Does a monsoon climate exist over South America?, J. Climate, 11, 1020-1040. 